\title{
The Promissory Basis of Section 90
}

\author{
Edward Yorio $†$ and Steve Thel $\uparrow \dagger$
}

\section{INTRODUCTION}

As conceived and drafted, Section 90 of the Second Restatement of Contracts is based primarily on principles of reliance. ${ }^{1}$ It rests on the proposition that a person who has led another to rely on a promise ought to compensate the other for any harm suffered in reliance. ${ }^{2}$ This Article shows that the prominence of reliance in the text of Section 90 and in the commentary on the section does not correspond to what courts do in fact. Judges actually enforce promises rather than protect reliance in Section 90 cases. $^{3}$

Section 90 has been described as the Restatement's "most notable and influential rule" and as "perhaps the most radical and expansive development of this century in the law of promissory liability."5 The section has had a profound influence on the law of contracts because it ratifies cases enforcing a promise in the absence of bargained-for consideration. ${ }^{6}$ By giving its impri-

$\dagger$ Professor of Law, Fordham University School of Law; A.B. 1968, Columbia; J.D. 1971, Harvard.

tt Associate Professor of Law, Fordham University School of Law. B.A. 1976, North Texas; J.D. 1979, Harvard. We are grateful to Melvin A. Eisenberg, Richard A. Epstein, E. Allan Farnsworth, Douglas Laycock, Joseph M. Perillo, and Alan Schwartz for helpful comments on a previous draft of this Article. We are also grateful to Jerry Choe for exceptionally able and conscientious research assistance.

1. In the Second Restatement, $\$ 90$ reads as follows:

(1) A promise which the promisor should reasonably expect to induce action or forbearance on the part of the promisee or a third person and which does induce such action or forbearance is binding if injustice can be avoided only by enforcement of the promise. The remedy granted for breach may be limited as justice requires.

(2) A charitable subscription or a marriage settlement is binding under Subsection (1) without proof that the promise induced action or forbearance.

RESTATEMENT (SECOND) OF CONTRACTS $\$ 90$ (1981).

In the original Restatement, $\S 90$ read as follows:

A promise which the promisor should reasonably expect to induce action or forbearance of a definite and substantial character on the part of the promisee and which does induce such action or forbearance is binding if injustice can be avoided only by enforcement of the promise.

RESTATEMENT OF CONTRACTS $\S 90$ (1932).

2. See infra text accompanying notes 62-64 and 170-74.

3. The title of the Article thus refers to $\$ 90$ in the courts.

4. E. Allan Farnsworth, CONTRACTS $\$ 2.19$, at 95 (2d ed. 1990).

5. Charles L. Knapp, Reliance in the Revised Restatement: The Proliferation of Promissory Estoppel, 81 ColuM. L. Rev. 52, 53 (1981).

6. The consideration doctrine is incorporated in $\$ 71$ of the Second Restatement, which reads in part as follows:

(1) To constitute consideration, a performance or a return promise must be bargained for. 
matur to those cases, the Restatement has encouraged courts to expand contractual liability beyond the traditional doctrinal limits of consideration. ${ }^{7}$

Most commentators, like the Second Restatement itself, hold that the objective of Section 90 is to protect promisees from loss caused by reliance on a promise. ${ }^{8}$ Some commentators even argue that Section 90 has contributed to the replacement of promise with reliance as the basis of contractual liability. ${ }^{9}$ As this Article shows, however, these commentators are wrong about the way courts have decided Section 90 cases. Rather than using Section 90 to compensate promisees for losses suffered in reliance, judges use it to hold people to their promises by granting specific performance or by awarding expectation damages.

Part I places the conflict between promise and reliance theories of Section 90 in historical perspective, showing that Section 90 of the original $R e$ statement was conceived and drafted primarily in terms of promise and that the changes adopted by the Second Restatement reflect an endorsement of reliance as the principle governing both liability and remedy under the section. Part II shows that the remedy courts routinely grant under Section 90 is specific performance or (if feasible) expectation damages. ${ }^{10}$ Cases granting less than

(2) A performance or return promise is bargained for if it is sought by the promisor in exchange

for his promise and is given by the promisee in exchange for that promise.

RESTATEMENT (SECOND) OF CONTRACTS § 71 (1981).

7. See Jay M. Feinman, Promissory Estoppel and Judicial Method, 97 HARV. L. REV. 678, 678 (1984) ("[C]ourts and scholars have come to recognize promissory estoppel as a principle of wide application."); Stanley D. Henderson, Promissory Estoppel and Traditional Contract Doctrine, 78 YaLE L.J. 343, 343 (1969) ("Recent decisions invoking Section 90 ... demonstrate that the doctrine of promissory estoppel embodied in that section is playing an important role in the fixing of limits of contractual responsibility." (footnote omitted)).

8. See, e.g., John D. Calamari \& Joseph M. Perillo, The LaW of ConTracts $\S 6-1$, at 273 (3d ed. 1987) ("[I]njury is what is required because without injury there would be no injustice in not enforcing the promise."); FARNSWORTH, supra note 4, § 2.19, at 102 ("One person has caused harm to another ... and is therefore held liable for the harm caused."); Benjamin F. Boyer, Promissory Estoppel: Requirements and Limitations of the Doctrine, 98 U. PA. L. REV. 459, 437 (1950) (no impelling reason to give promisee more than detriment suffered in reliance); Melvin A. Eisenberg, Donative Promises, 47 U. CHI. L. REV. 1,32 (1979) ("Relied upon donative promises should be enforced to the extent of the reliance."); L.L. Fuller \& William R. Perdue, Jr., The Reliance Interest in Contract Damages (pts. 1-2), 46 YALE L.J. 52, 373, 69 (1936-1937) ("If reliance is here the sine qua non of legal intervention, then protection of the reliance interest is obviously a part of the motive actuating courts in such cases."); Michael B. Metzger \& Michael J. Phillips, The Emergence of Promissory Estoppel as an Independent Theory of Recovery, 35 RUTGERS L. REV. 472, 499 (1983) (promissory estoppel doctrine may be used to protect promisee's reliance interest); Warren A. Seavey, Reliance Upon Gratuitous Promises or Other Conduct, 64 HARV. L. REv. 913, 926 (1951) ("The wrong is not primarily in depriving the plaintiff of the promised reward but in causing the plaintiff to change position to his detriment."); Warren L. Shattuck, Gratuitous Promises-A New Writ?, $35 \mathrm{MICH}$. L. REV. 908, 944 (1937) ("[T]he reason for allowing the gratuitous promisee an action is his injury through reliance and not the promisor's act of promising.").

9. See P.S. ATTYA, THE RISE AND FALl OF FREEDOM OF CONTRACT 777 (1979) (expansion of $\S 90$ "indicates a resurgence of reliance-based liability at the expense of consensual liability"); GRANT GILMORE, THE DEATH OF CONTRACT 72 (1974) (reliance principle of $\$ 90$ has effectively swallowed up bargain principle); cf. FARNSWORTH, stura note 4 , $\$ 2.19$, at 102 (justification for liability under $\$ 90$ may be founded on tort principle of compensation for harm).

10. If the promisor promises to refrain from acting in a particular way, expectancy relief may take the form of a negative injunction ordering the promisor not to act in violation of her promise. See infra text accompanying notes $224-27$. 
expectancy relief are relatively rare, and the only substantive explanation for that outcome is a defect in the promise or in the proof of the promise. By fully enforcing promises with expectancy relief rather than limiting the remedy to reliance, ${ }^{11}$ courts belie the claim that the objective of Section 90 is to compensate promisees for losses suffered in reliance. Part III shows that courts may enforce a promise under Section 90 in the absence of reliance or detriment. Conversely, courts may not enforce a promise under the section despite detrimental reliance by the promisee. Both results are inconsistent with a reliancebased theory. Part IV shows that the critical question for courts under Section 90 is which promises to enforce, not what remedy to award or how to protect reliance. A promise will be fully enforced under the section if the promise is proven convincingly and is likely to have been serious and well considered when it was made. Issues of both liability and remedy turn on promise, showing that the basis of Section 90 in the courts is promise, not reliance. ${ }^{12}$

Our findings indicate that Section 90, like the doctrine of consideration, works to enforce promises that are likely to be serious. The role of the consideration doctrine in screening for serious promises is well understood. ${ }^{13} \mathrm{Al}-$ though it is not so widely recognized, the prospect of definite and substantial reliance generally required under Section 90 also screens for seriously considered promises. ${ }^{14} \mathrm{~A}$ promisor who can foresee definite and substantial reliance is likely to be careful about making a promise.

The consideration doctrine and Section 90 have a common remedial implication as well as a common screening function. If a promise is identified as serious through a finding of either consideration or a prospect of definite and substantial reliance, the court will enforce it. In our system, enforcing a promise generally means awarding expectancy relief. ${ }^{15}$

Although many commentators, and the Second Restatement itself, regard reliance as an appropriate measure of relief, courts routinely award specific

11. See infra text accompanying notes $46-48$ (discussion of difference between expectation and reliance damages).

12. Individuals may be held liable for causing harm by statements that do not satisfy the requirements set out by courts for a $\$ 90$ promise. Examples include defective or unproven promises and negligent misrepresentations that induce another to rely to her detriment. See, e.g., D'Ulisse-Cupo v. Board of Directors of Notre Dame High Sch., 520 A.2d 217 (Conn. 1987) (no liability under $\$ 90$ because no promise made, but possible liability for negligent misrepresentation). The theory of liability in such cases derives from the tort concept of compensation for harm rather than from the contractual principle of enforcing promises on which $\$ 90$ is based. Sce infra text accompanying notes 360-63.

13. See 1 ARThur L. CORBIN, CoRBIN ON CONTRACTS $\S 111$, at 496 (1963) ("The existence of some kinds of consideration may evidence an intention to be legally bound or a serious intention to keep the promise."); James B. Ames, Two Theories of Consideration, 13 HARV. L. REV. 29, 42 (1899) (requirement of consideration "gives the formality needed as a safeguard against thoughtless gratuitous promises"); Lon L. Fuller, Consideration and Form, 41 COLUM. L. REV. 799-800 (1941) (formality may serve cautionary function, as does consideration).

14. See infra text accompanying notes $84-100$.

15. See RESTATEMENT (SECOND) OF CONTRACTS $\S 347$ (1981); CALAMARI \& PERILlo, supra note 8 , $\S 14-4$, at 591-92; FARNSWORTH, supra note 4 , § 12.1, at 839-40. 
performance or expectation damages in Section 90 cases. ${ }^{16}$ Faced with the primacy of expectancy relief in the courts and the prevailing reliance theory of Section 90, some commentators conclude that contract law is incoherent. ${ }^{17}$ Others have tried to explain the primacy of expectation with theories of Section 90 that fail to address many of the reported cases, including those cases that led to the promulgation of Section 90 in the first place. ${ }^{18}$ This Article offers a coherent and inclusive explanation of the Section 90 cases, albeit one that may be in keeping with what was once considered an entirely conventional, promise-based view of contract law.

Section 90 reflects the legal realist's recognition that the best way to understand law is to analyze what courts are doing instead of trying to force cases into accepted theories. ${ }^{19}$ In particular, Section 90 recognizes that courts often enforce promises in the absence of a bargain. Ironically, soon after escaping the shackles of bargain theory, scholars embraced a reliance theory of Section 90 that does not conform to the reality of the reported cases. This Article shows that the original cases on which Section 90 was based and the more recent cases that purport to follow it are best explained by an old conception of contract law: courts respond to an impulse to enforce serious promises.

Our thesis is not that the basis of Section 90 ought to be promise. Rather, we describe and analyze the reported cases and show that the basis of the

16. See, e.g., Mary E. Becker, Promissory Estoppel Damages, 16 HoFsTRA L. REv. 131, 163 (1987) ("[I]n donative cases, courts routinely afford full enforcement. In commercial, contract-based cases, expectation damages are similarly available provided that expectation damages would be available under normal limits on expectation damages."); Daniel A. Farber \& John H. Matheson, Beyond Promissory Estoppel: Contract Law and the "Invisible Handshake," 52 U. CHI. L. REV. 903, 909 (1985) ("IR]eliance plays little role in the determination of remedies [under $\$ 90]$. . . [R]ecent cases are heavily weighted towards the award of full expectation damages." (citations omitted)); Feinman, supra note 7, at 687-88 (in $\$ 90$ cases, availability of specific performance is same as in bargain cases and typical damages remedy is expectation damages); $c f$. JOHN E. MURRAY, MURRAY ON CONTRACTS $\S 66$, at 283 (3d ed. 1990) ("[I]t is clear that the typical recovery protects the expectation interest, i.e., full enforcement of the promise ....").

17. See, e.g., Feinman, supra note 7.

18. See, e.g., Farber \& Matheson, supra note 16. Their theory-that $\S 90$ works to enforce promises made in furtherance of economic activity-requires that donative promises be ignored and that charitable pledges be regarded as furthering economic activity. See id. at $930,937$.

19. See Karl L. Llewellyn, Some Realism about Realism-Responding to Dean Pound, 44 HARV. L. REV. 1222 (1931). 
section is promise. ${ }^{20}$ Because Section 90 conventionally is viewed as the archetypical reliance provision, our conclusions support the claim that the law of contracts is generally based instead on promise. ${ }^{21}$ Conversely, our findings undermine the contention that contract law is being absorbed into a general theory of civil liability based on the tort concept of compensation for harm. ${ }^{22}$ If contract were dead (or dying), signs of rigor mortis would surely appear in the cases decided under Section 90.23 But the governing principle of Section 90 in the courts is promise, and the central importance of promise shows that contract remains a vital theory of obligation distinct from tort. Although our primary objective is to describe and analyze the cases, our conclusions may have important implications for the normative debate between promise and reliance theorists because a normative legal theory derives part of its strength from application and acceptance by the courts. Those who contend that reliance ought to be the basis of contract need to explain why their arguments have failed to persuade judges to resolve cases arising under the archetypical reliance provision in accordance with reliance principles. ${ }^{24}$

\section{A History OF SECTION 90}

The Second Restatement of Contracts revised Section 90 of the First Restatement in three major respects. ${ }^{25}$ First, it eliminated the requirement that

20. A person's interpretation of a case may reflect normative bias. The reader may wonder, therefore, whether our description and analysis of the $\$ 90$ cases may be affected by a normative judgment favoring promise over reliance. We discuss in detail in the text virtually all of the leading cases that are said to support reliance, allowing the reader to evaluate the validity of our interpretations. For what it's worth, we are not aware that we favor promise on normative grounds. In fact, we both believe that any harm suffered in reliance on a promise is a powerful reason for judicial intervention. Moreover, before beginning research for this Article, we both assumed (erroneously, as it turns out)-and taught in our contracts classes-that the basis of $\S 90$ is reliance.

That said, we recognize that others may read some of the cases discussed herein as support for a reliance theory of $\S 90$ or as neutral on the choice between reliance and promise. We believe, however, that the evidence presented herein is so extensive and compelling that whatever the effect of possible normative bias in reading particular cases, our conclusion that the basis of $\S 90$ in the courts is promise is correct.

21. See generally ChARLes FRIED, CONTRACT AS PROMISE (1981) (stating a promissory view of contracts).

22. See generally GILMORE, supra note 9 (classical view of contract law superseded by tort-related principles).

23. Professor Grant Gilmore used $\S 90$ as a paradigm for his theory that contract law is being absorbed into a general theory of civil liability based primarily on tort-related concepts. $1 d$. at 69-72,89-90. Gilmore contended that $\S 90$ is based on a principle of reliance that "has, in effect, swallowed up the bargain principle of $\S 75$ [of the First Restatement]." Id. at 72. This Article concludes that $\S 90$ (like $\S 75$ ) is based on promissory principles very different from the tort concept of compensation for harm.

24. The classic and most influential analysis of contract law in terms of reliance is Fuller \& Perdue, supra note 8. Among Fuller and Perdue's contemporary successors, Professor Patrick Atiyah has presented the most complete and sophisticated arguments for reliance as the basis of contract. See P.S. ATTYAH, ESSAYS ON CONTRACT 79-91 (1986); P.S. ATTYAH, PROMISES, MORALS AND LAW 66-68, 202-15 (1981); ATIYAH, supra note 9 , at 764-79.

25. See supra note 1 (quoting both Restatements). The Second Restatement also changed the First Restatement by allowing a third person's reliance to serve as a ground for enforcing a $\$ 90$ promise. See RESTATEMENT (SECOND) OF CONTRACTS $\$ 90(1)$ (1981). For an analysis of the changes in $\$ 90$ wrought 
the action or forbearance foreseen by the promisor and induced by the promise be "of a definite and substantial character." ${ }^{26}$ Second, it provided that "[t]he remedy granted for breach may be limited as justice requires." 27 Third, it added a new subsection providing that "[a] charitable subscription or a marriage settlement is binding ... . without proof that the promise induced action or forbearance." 28 These changes illuminate the respective theories of the First and Second Restatements regarding enforcement of promises in the absence of a bargain. To understand the importance of these changes, it is necessary to analyze the reasons for the original provision in the First Restatement and the explanations given for the revisions in the Second.

\section{A. The Remedy for Breach}

During the 1926 proceedings of the American Law Institute, a member of the audience asked Professor Samuel Williston, the reporter for the First Restatement of Contracts, about the following hypothetical. Uncle, aware that Nephew is thinking about buying a car, promises to give Nephew $\$ 1000$. Nephew buys a car for $\$ 600$. If Uncle reneges on his promise and Nephew sues, what does the Nephew recover, $\$ 1000$ or $\$ 600$ ? Williston responded that Uncle would be liable for $\$ 1,000$, the amount of his promise. ${ }^{29}$ Although Williston's response satisfied the immediate questioner, ${ }^{30}$ Frederic Coudert, the famous New York lawyer, challenged Williston's answer in an exchange that has since become one of the most quoted passages in American contract law:

MR. COUDERT: Allow me to trespass once more, Mr. Reporter, by asking this question. Please let me see if I understand it rightly. Would you say, Mr. Reporter, in your case of Johnny and the uncle, the uncle promising the $\$ 1000$ and Johnny buying the car-say, he goes out and buys the car for $\$ 500$ - that uncle would be liable for $\$ 1000$ or would he be liable for $\$ 500$ ?

MR. WILLISTON: If Johnny had done what he was expected to do, or is acting within the limits of his uncle's expectation, I think the uncle would be liable for $\$ 1000$; but not otherwise.

MR. COUDERT: In other words, substantial justice would require that uncle should be penalized in the sum of $\$ 500$.

MR. WILLISTON: Why do you say "penalized"?. . . .

\footnotetext{
by the Second Restatement, see Knapp, supra note 5, at 55-61.

26. RESTATEMENT OF CONTRACTS $\$ 90$ (1932).

27. RESTATEMENT (SECOND) OF CONTRACTS $\$ 90$ (1981).

28. Id.

29. See Proceedings at Fourth Anmual Meeting, 4 A.L.I. PROC. $95-96$ (1926) [hereinafter 1926 Proceedings].

30. See id.
} 
MR. COUDERT: Because substantial justice there would require, it seems to me, that Johnny get his money for his car, but should he get his car and $\$ 500$ more? I don't see. ${ }^{31}$

Coudert's bewilderment was shared by other members of the audience, who returned repeatedly to the car hypothetical:

HOMER ALBERS (Massachusetts): I am still not satisfied that Johnny could have the car and $\$ 500$ both, if he bought a second-hand Buick for $\$ 500 \ldots$. . $^{32}$

JUDGE PAGE: To get back to Johnny, how is injustice going to be done Johnny if he is not going to get the other $\$ 500$; how is he going to be done an injustice, if he only paid $\$ 500$ for the car? ${ }^{33}$

In the face of this assault, Williston stood his ground:

MR. WLLISTON: Either the promise is binding or it is not. If the promise is binding it has to be enforced as it is made. ${ }^{34}$

Subsequent authorities generally have sided with Williston's critics, often expressing their disagreement with Williston in terms more forceful than Coudert's. ${ }^{35}$ Professor Melvin Eisenberg, for example, describes the remedial outcome endorsed by Williston as "apparently extraordinary," "seem[ingly] counterintuitive," and an example of "the extreme conceptualism of which [Williston] was occasionally capable." ${ }^{136}$ By identifying Williston's response with "conceptualism," Eisenberg places the exchange at the center of the debate

31. Id. at $98-99$.

32. Id. at 101 .

33. Id. at 103.

34. Id.

35. See CALAMARI \& PERILLo, supra note 8, § 6-6, at 290 (Williston's "overly conceptual approach [to the remedy for breach] has very likely hindered full judicial acceptance of the doctrine" of promissory estoppel); Boyer, supra note 8, at 487 ("[I]njustice ... is avoided when [the promisee] is protected to the extent of his expenditures made in reliance upon the gratuitous promise."); Eisenberg, supra note 8, at 24-25 (result endorsed by Williston is "apparently extraordinary" and "seem[s] counterintuitive"); Fuller \& Perdue, supra note 8, at 64 (most arguments for expectation damages do not apply to nonbargain promises); Metzger \& Phillips, supra note 8, at 499 ("[T] he injustice to the promisor wrought by fully enforcing the promise in such cases may have retarded the utilization of promissory estoppel."); Seavey, supra note 8, at 926 ("Damages should not exceed the loss caused by the change of position ...."); Shattuck, supra note 8, at 944 n.110 ("[D]amages should ... be restricted to a sum which will reimburse the promisee for his expenditures ... attending his reliance on the promise."); Comment, Once More into the Breach:Promissory Estoppel and Traditional Damage Doctrine, 37 U. CHI. L. REv. 559, 563 (1970) ("Williston's view ... seemed to sacrifice common sense to theoretical consistency ....").

36. See Eisenberg, supra note 8, at 24. 
during the 1920's between formalism and legal realism. ${ }^{37}$ Williston's insistence that the promise is either binding or not invites the response that the extent to which the promise should be enforced depends on the reason for judicial intervention. ${ }^{38}$ If the reason is to protect the promisee's reliance interest, the remedy should be limited to reliance damages measured by the cost of the car (presumably less its resale value). ${ }^{39}$

Sensitive analysis of Williston's comments in their entirety reveals, however, that his view about the appropriate remedy for breach was a product not of rigid formalism, ${ }^{40}$ but of a conception of Section 90 radically different from that of his critics. To them, Section 90 protects the promisee's reliance interest. $^{41}$ To Williston, Section 90 enforces certain types of promises. Although Williston described justifiable reliance by the promisee as the "binding thread of principle" in the cases, ${ }^{42}$ he did not regard protecting reliance as the ultimate objective of Section $90 .{ }^{43}$ Rather, reliance joins with the other requirements laid out in Section 90 to make a promise enforceable. ${ }^{44}$ Where the critics focus on the behavior of the promisee and on the harm she has suffered, Williston repeatedly emphasized the promisor and the promise made:

I should be of the opinion that it was unjust under the circumstances ... for the promisor not to do what he said he would.

....

.... [T] $]$ his section covers a case where there is a promise to give and the promisor knows that the promisee will rely on the proposed gift in certain definite ways. ise.

$\ldots .[T]$ he proposition is that the court should enforce the prom-

37. See William Twining, Karl Llewellyn and the Realist Movement 26-83 (1973) (survey of rise of legal realism during period from 1870 to 1931 ).

38. See Fuller \& Perdue, supra note 8, at 53-66 (analysis of the policies served by contract remedies); cf. Eisenberg, supra note 8 , at 32 ("Relied-upon donative promises should be enforced to the extent of the reliance.").

39. Eisenberg, supra note 8, at 26 (nephew's financial loss is the difference between the cost of the car and its resale value); see also FARNSwORTH, supra note 4, at 100 ("If . . the ground of the promisee's recovery were regarded as the reliance interest, it would seem appropriate to limit recovery to the value of that interest-the cost to the promisee of the detriment that the promisee incurred in reliance on the promise.").

40. Cf. E. Allan Farnsworth, Contracts Scholarship in the Age of the Anthology, 85 MICH. L. REv. $1406,1456-57$ (1987) (Williston's views on promissory estoppel exhibit signs of "legal realism" and "liberality").

41. See sources cited supra note 8 .

42. Commentaries on Contracts Restatement No. 2, 4 A.L.I. Proc. 19-20 (1926) (remarks of Samuel Williston, Reporter) [hereinafter Commentaries].

43. That Williston did not regard protecting reliance as the ultimate objective of $\S 90$ is illustrated by his insistence that reliance alone, even if substantial, would not be sufficient to entitle the promisee to relief. See Commentaries, supra note 42, at 20; 1926 Proceedings, supra note 29, at 92-93.

44. See infra text accompanying notes 76-77, 88-89, 93-100 (under Williston's view, promisor should reasonably foresee reliance of a definite and substantial character for promise to be enforceable). 
Either the promise is binding or it is not. If the promise is binding it has to be enforced as it is made.

$\ldots . .[T]$ he question of damages for breach of a promise is ordinarily such a sum that will put the promisee in as good a position as he would have been in if the promise had been kept, not as good a position as he would have been in if the promise had not been made .... ${ }^{45}$

The rejection of Williston's conception of Section 90 by many commentators may be due in large part to the publication in 1936 of Fuller and Perdue's seminal article on contract damages. ${ }^{46}$ Fuller and Perdue analyzed contract remedies in terms of three interests of the promisee: restitution, reliance, and expectation. Restitution entitles the promisee to recapture a benefit to which the promisor is not entitled in light of her breach; reliance damages compensate the promisee for actual harm caused by the promise; expectation damages put the promisee in the same position as if the promise had been kept. ${ }^{47}$ According to Fuller and Perdue, the promisee's claim to expectation damages is the weakest. These damages, they argue, go beyond compensating for an actual loss or stripping the promisor of unjust enrichment, to placing the promisee in a better position than the one she was in before the promise was made..$^{48}$

Despite placing expectation damages at the bottom of the remedial hierarchy, Fuller and Perdue recognized that the normal measure of recovery for breach of contract was expectation damages. ${ }^{49}$ They offered two principal explanations for this phenomenon. First, expectation damages may serve as a surrogate for measuring reliance in the form of foregone opportunities..$^{50}$ If, for example, the promisee could have obtained another contract on similar terms, expectation damages are justifiable because they compensate for the loss suffered by the promisee in passing up the other deal. Second, expectation damages further a policy of encouraging and facilitating reliance on business transactions, with the result that economic activity is generally stimulated. ${ }^{51}$ Reliance would be discouraged-and the policy of stimulating economic activity threatened-if promisees were limited to recovering reliance damages for breach of promise. ${ }^{52}$

45. 1926 Proceedings, supra note 29 , at $87,89,91,103,111-12$.

46. Fuller \& Perdue, sipra note 8.

47. Id. at 53-54.

48. Id. at 56-57; see also Becker, sippra note 16, at 142.

49. Fuller \& Perdue, supra note 8, at 57.

50. Id. at 60-61.

51. Id. at 61; see also JOHN P. DAWSON, GIFTS AND PROMISES 221 (1980) ("[A] sufficient reason for enforcing a promise is that it is part of an agreed exchange which would enable each party to secure from the other an act or result that he sought.").

52. See Fuller \& Perdue, supra note 8, at 61-62. 
As Fuller and Perdue noted, ${ }^{53}$ their analysis leaves little room for expectation damages in the context of a Section 90 that was originally conceived as a mechanism for enforcing donative promises..$^{54}$ Economic utility is difficult to discern in donative promises because the parties are not engaged in the exchanges "by which production is organized in a capitalistic society."55 Moreover, because the promisee by definition is not exchanging anything for the promise, she typically will not have given up another deal in reliance on the promise. ${ }^{56}$ Although there may be instances in which the promisee's reliance on a gratuitous promise assumes nonquantifiable forms justifying expectation damages as a surrogate for measuring reliance, ${ }^{57}$ Fuller and Perdue's analysis leads to the conclusion that the proper remedy under Section 90 is reliance whenever, as in the car example, the amount of the promisee's loss can be quantified. ${ }^{58}$

Since the publication of Fuller and Perdue's article, it has become conventional to view contract remedies in terms of the promisee's interests in the remedy awarded. ${ }^{59}$ Fuller and Perdue's pervasive influence is shown most dramatically by the first section dealing with remedies in the Second Restatement of Contracts. Entitled "Purposes of Remedies," it lays out the three interests of the promisee identified in the Fuller and Perdue article, ${ }^{60}$ which

53. See id. at 64 ("Most of the arguments for the rule measuring damages by the expectancy which we developed ... have no application to" $\$ 90$ promises.).

54. See Commentaries, supra note 42 , at 16-19 (review of nonbargain cases making it necessary to adopt $\$ 90$ of the First Restatement); 1926 Proceedings, supra note 29, at 106-07 (remarks of Prof. Williston to same effect); Randy E. Barnett \& Mary E. Becker, Beyond Reliance: Promissory Estoppel, Contract Formalities, and Misrepresentations, 15 HOFSTRA L. REV. 443, 449 (1987) ( $\$ 90$ originally "limited to nonbargain promises in donative settings"); Feinman, supra note 7, at 680 ("Section 90 was abstracted ... as a substitute for consideration to ameliorate the Restatement's strict bargain requirement in a limited class of cases involving gratuitous promises." (footnote omitted)).

55. See Fuller \& Perdue, supra note 8, at 65; $c f$. Eisenberg, supra note 8, at 4 ("It is far from clear that any independent social interests are implicated by [donative] promises."). Judge Richard Posner has argued that enforcement of gratuitous promises improves efficiency by increasing the value of the promise to the promisee at no cost to the sincere promisor. See Richard Posner, Gratuitous Promises in Law and Economics, 6 J. LEGAL STUD. 411, 411-12 (1977). Professor Jeffrey Harrison has questioned whether efficiency concerns have affected judicial decisions in the context of promissory estoppel. See Jeffrey Harrison, Trends and Traces: A Preliminary Evaluation of Economic Analysis in Contract Law, 1988 ANN. REV. AM. L. 73, 86-88.

56. See Becker, supra note 16, at 135-36; Fuller \& Perdue, supra note 8, at 65; Comment, supra note 35 , at 568 .

57. See Becker, supra note 16, at 139; Eisenberg, supra note 8, at 26-31.

58. See Fuller \& Perdue, supra note 8, at 64-65.

59. For examples of discussions of remedies under $\$ 90$ that are influenced by Fuller and Perdue, see Calamari \& PERILlo, supra note 8, § 6-6, at 291; Becker, supra note 16, at 140-44; Boyer, supra note 8, at 462; Eisenberg, supra note 8, at 1-2. Even those commentators who find that expectation damages are routinely granted under $\$ 90$ seem compelled to reconcile that outcome with Fuller and Perdue's analysis. See, e.g., Becker, supra note 16, at 140-44.

60. See RESTATEMENT (SECOND) OF CONTRACTS \$ 344 (1981). The approach of the Second Restatement represents a significant change from the First Restatement, which did not recognize the reliance interest. See Fuller \& Perdue, supra note 8, at 89-90, 400-01. 
is prominently cited in the reporter's note following the section. ${ }^{61}$ The section presumes that the sole purpose of contract remedies is to protect interests of the promisee. In keeping with this presumption, the Second Restatement added language allowing courts to limit the remedy in Section 90 cases, ${ }^{62}$ thereby sanctioning the award of reliance damages. ${ }^{63}$ If contract remedies serve to protect interests of the promisee and if the promisee's claim under Section 90 derives from injury to her reliance interest, the remedy awarded ought to be limited to reliance damages. ${ }^{64}$

Contract remedies look entirely different, however, when viewed from the perspective of the promisor. With this shift in focus come very different conclusions regarding the proper remedy for breach. Professor Charles Fried is the most recent expositor of a promisor-based approach to contract remedies. Fried explains much of contract law in terms of the moral obligation of promise. ${ }^{65}$ His primary focus is on the promisor, who has an interest in requiring that promises be kept so that others will take her at her word. By enforcing contracts, the legal system supports principles of trust and integrity. ${ }^{66}$ From this perspective, Fried concludes that the proper remedy for breach of contract is expectation damages that put the promisee in the same position in which she would have been had the promisor kept her word. ${ }^{67}$

Fuller and Fried offer radically different explanations of contract remedies. ${ }^{68}$ For the purposes of this Article, it is not necessary to choose between them. It is important to recognize, however, that Williston, with his emphasis

61. RESTATEMENT (SECOND) OF CONTRACTS $\$ 344$ reporter's note (1981); see also E. Allan Farnsworth, Some Prefatory Remarks: From Rules to Standards, 67 CORNELL L. REV. 634, 635 (1982) (acknowledging influence of Fuller and Perdue on $\S 344)$.

62. See RESTATEMENT (SECOND) OF CONTRACTS § 90(1) (1981).

63. See Eisenberg, supra note 8 , at 26 (purpose of added sentence in $\S 90$ was to sanction use of reliance damages); Knapp, supra note 5, at 55 (language permitting remedy to be limited is "a response to numerous writers over the years who have differed with Professor Williston's assertion that a promise enforced under Section 90 ... must be enforceable . . . to the full extent of the promised expectation").

64. See W. David Slawson, The Role of Reliance in Contract Damages, 76 CORNELL L. REV. 197, 236 (1990) ("[A]ttempts to replace the expectation measure with the reliance measure . . . equate the measure of compensation with the grounds for enforcement ...."). Although the logic of its position leads to the conclusion in the text, the Second Restatement does not fully endorse reliance damages as the normal remedy in $\S 90$ cases. Instead, in what appears to be a concession to reported decisions, the Restatement comments that "[a] promise under this section is a contract, and full-scale enforcement by normal remedies is often appropriate." RESTATEMENT (SECOND) OF CONTRACTS $\S 90 \mathrm{cmt}$. d (1981); see infra text accompanying note 174.

65. See FRIED, supra note 21, at 14-17.

66. See id. at 15-17.

67. See id. at 17-21. Given Fried's emphasis on promise, it is curious that he seems to accept the view that $\S 90$ is based on detrimental reliance. His acceptance of this position may be due to a misconception that the cases under $\S 90$ tend to award reliance damages. See id. at 25 ; see infra text accompanying note 278. Fried's error may also reflect a failure to recognize that $\S 90$ of the First Restatement contains standards for imposing liability which are more consistent with his own promise principle than with a theory of detrimental reliance. See infra text accompanying notes 97-100.

68. That Fuller and Perdue almost entirely overlooked the promisor in formulating their theory of contract remedies appears most clearly in their discussion of the expectation interest, in which the explanations they gave for the prevalence of expectancy relief derive solely from interests of society and of the promisee. See Fuller \& Perdue, supra note 8, at 57-63. 
on promise and on the promisor, was proceeding from premises much more akin to Fried's than to Fuller and Perdue's. This is not to say that Williston conceptualized Section 90 primarily in terms of a moral obligation of promise. The key to Williston's position is found instead in the first sentence of the 1925 proceedings of the American Law Institute on the Restatement of Contracts in which Williston states: "The endeavor in this Restatement is to restate the law as it is, not as a new law."69 Applying this principle to Section 90, Williston knew he was on firm ground in insisting that the remedy for breach was expectation damages or specific performance because the reported cases so held. While the critics repeatedly contended that the nephew should be limited to damages measured by the cost of the car, Williston was equally persistent in noting that the cases held otherwise. ${ }^{70}$ If the Restatement was meant to restate the law, how could Section 90 provide for reliance damages when the remedy awarded by courts was either specific performance or expectation damages?

Although Williston's defense of expectation damages was based on the reported decisions, he almost certainly would have defended expectation damages on normative grounds as well. Thus, he disagreed with Coudert's contention that to enforce a Section 90 promise with expectancy relief would be to penalize the promisor, and he insisted that "[e]ither the promise is binding or it is not." "W1 Williston also distinguished between actions grounded in promise and actions based on equitable estoppel or deceit. ${ }^{72}$ For breach of promise, the defendant may be liable even in the absence of misrepresentation at the time of the promise. ${ }^{73}$ By contrast, equitable estoppel or deceit is based on the defendant's misrepresentation of fact independent of her promise. ${ }^{74}$ As a remedy for equitable estoppel or deceit, damages measured by the harm suffered by the plaintiff might be appropriate; for breach of promise, Williston believed that the remedy was properly based on the promise, i.e., specific performance of ings].

69. See Proceedings at Third Annual Meeting, 3 A.L.I. PRoc. 159 (1925) [hereinafter 1925 Proceed-

70. See 1926 Proceedings, supra note 29, at 99, 104, 112.

71. Id. at 103; see supra text accompanying note 34 .

72. See 1926 Proceedings, supra note 29, at 89-90 (remarks of Prof. Williston) ("I should like to confine the meaning of the word [estoppel] to a misrepresentation of some fact that was relied upon. There is no misrepresentation of fact here; there is simply a gratuitous promise . . ..").

73. See id. at 93 (remarks of Prof. Williston) ("To call a promise deceit merely because the promisor, although intending to keep it when he makes [it], afterwards decides not to, is to my mind a misuse of language.").

74. See 1925 Proceedings, supra note 69, at 166 (remarks of Prof. Williston) ("If they simply make a statement that they are true, then it is within the doctrine of estoppel; I should define estoppel as a misrepresentation of fact on which the other party justifiably relies ....").

Some of the cases decided before the promulgation of $\S 90$ invoked the doctrine of equitable estoppel to hold the promisor liable for what would now be called promissory estoppel. See, e.g., Ricketts v. Scothorn, 77 N.W. 365 (Neb. 1898). One commentator attributes the misapplication of equitable estoppel in these cases to the absence of a recognized doctrine of promissory estoppel. See MURRAY, supra note $16, \S 66(\mathrm{~A})(\mathrm{I})$, at $274-75$. 
the promise itself or expectation damages measured by the value of the promise. $^{75}$

\section{B. The Requirements of Foreseeability, Definiteness, and Substantiality}

Williston recognized that not all promises, nor even all relied-upon promises, were enforceable. ${ }^{76}$ His task was to circumscribe the scope of Section 90 so that it covered only those nonbargain promises courts would enforce. The original Section 90 sought to accomplish this objective in three ways: first, the promise must be such that the promisor should reasonably expect it to induce action or forbearance by the promisee; second, the action or forbearance expected must be "of a definite and substantial character"; third, the promise must actually induce such action or forbearance. ${ }^{77}$

Subsequent commentators have criticized the first two limitations. ${ }^{78}$ Professor Eisenberg would scrap the requirement that the reliance be within the reasonable expectation of the promisor in favor of a rule that would make any reasonable reliance compensable. ${ }^{79}$ Eisenberg prefers this rule in part because it shifts attention away from "the contours of the promise-breaker's expectation" and toward "the reasonableness of the innocent promisee's reliance." 80

As Eisenberg points out, his revision would not affect the outcome of many cases ${ }^{81}$ If the promisee's reliance is reasonable, it is likely also to be within the reasonable contemplation of the promisor. But it is certainly possible to conceive of cases in which the outcome would vary depending on the rule applied. Suppose, for example, that Uncle promises miserly Nephew $\$ 1000$. If Uncle has a reputation for keeping his word, it may be reasonable for Nephew to rely on the promise by buying a new automobile. Given Nephew's reputation for miserliness, however, his spending rather than saving the $\$ 1000$ may not be reasonably expected by Uncle. Eisenberg would enforce the promise

75. Although Williston emphasized the distinction between promise and equitable estoppel or deceit, the connection between this distinction and the remedy awarded for each wrong was made most forcefully by a questioner who agreed with Williston's conclusion that expectation damages ought to be the measure of recovery under $\S 90$ :

MR. TUNSTALL: That is how I should interpret it, because otherwise the point made by Mr. Coudert would limit recovery to the price of the Ford and so also an action of deceit would limit it to the price of a Ford; but if it is a promise and the promise is binding, the uncle would be bound for $\$ 1000$ irrespective of the detriment suffered by the promisee.

1926 Proceedings, supra note 29, at 96 (remarks of R. Tunstall).

76. See Commentaries, supra note 42 , at 20 ("There are numerous cases in which [justifiable reliance of the promisee] is held not sufficient to make a gratuitous promise binding."); 1926 Proceedings, supra note 29, at 97 (remarks of Prof. Williston) ("There is no broad doctrine that wherever a man makes a promise, a gratuitous promise, and the other relies upon it, the promisee can recover on the promise.").

77. See RESTATEMENT OF CONTRACTS $\S 90$ (1932).

78. See Boyer, supra note 8, at 478-79; Eisenberg, supra note 8, at 20-23; Fuller \& Perdue, supra note 8 , at 420 .

79. See Eisenberg, supra note 8, at 20-21.

80. See id. at 21 .

81. See id. 
(at least to the extent of the Nephew's reliance). Under Williston's formulation and under the First Restatement, the Nephew would not be compensated ${ }^{82}$ because his reliance was not within the reasonable expectation of the promisor. ${ }^{83}$

Cases like this are unusual, however, and the issue might not be worth pursuing if not for what it says about the huge theoretical gulf separating Williston and his critics. If the objective of Section 90 is to protect reliance, then reasonable reliance alone justifies a remedy. But if, as Williston believes, the goal of Section 90 is to enforce certain nonbargain promises, it is critical to provide standards for determining which promises should be enforced.

The framework set out in the First Restatement is best understood by bearing in mind that Section 90 has the effect of eliminating the requirement of bargained-for consideration. ${ }^{84}$ But Section 90 ensures that some of the functions of the bargain requirement are served in other ways. Among other things, the presence of a bargain helps to identify promises on which the promisor has seriously reflected. ${ }^{85}$ If she made the promise to get something in return, her promise was sufficiently well considered to justify legal enforcement. ${ }^{86} \mathrm{By}$ contrast, donative promises may be made impulsively. ${ }^{87}$ Section 90 identifies well-considered donative promises for enforcement by requiring that reliance be within the reasonable expectation of the promisor, thereby distinguishing between relatively casual promises and promises that, precisely because reliance by the promisee is expected, are likely to be more serious; a promise-based law of contracts would enforce only the latter..$^{88}$

82. The point in the text is confirmed by Williston's discussion of a hypothetical in which an uncle promises his nephew $\$ 1000$ expecting that the nephew will invest the gift. 1926 Proceedings, supra note 29 , at 93 . Williston concludes that if the nephew instead spends the money by launching "into high life," he would not be compensated, because the uncle did not reasonably foresee this action by the nephew in reliance on the promise. Id.; see also Commentaries, supra note 42, at 20 ("action should reasonably have been expected by the promisor" for promise to be enforceable).

83. Even if the nephew was a spendthrift rather than a miser, he would not be compensated under the First Restatement because, while the uncle could anticipate that the nephew would spend the $\$ 1000$, the uncle did not reasonably expect particular action by the nephew in reliance on the promise. See Commentaries, supra note 42 , at 20 ("A promise of a thousand dollars generally without specification of the purpose will not bind the promisor.").

84. See Feinman, supra note 7, at 680 ("Section 90 was abstracted . . . as a substitute for consideration to ameliorate the Restatement's strict bargain requirement.").

85. See supra text accompanying notes 13-14.

Another function of the consideration requirement is evidentiary. See Fuller, supra note 13, at 800 . If the promisor obtained something in an exchange, it is likely that she actually made a promise. See Melvin A. Eisenberg, The Bargain Principle and its Limits, 95 HARV. L. REV. 741, 744 (1982). The evidentiary function of the bargain is replaced in $\S 90$ by the fact that the promisee relied in a substantial manner, making it more likely that a promise was made. See infra text accompanying notes 331-32.

86. See FRIED, supra note 21 , at 38 ("Requiring an exchange increases the chance that the parties had in contemplation serious business with serious consequences.").

87. See Eisenberg, supra note 8, at 5; Fuller, supra note 13, at 799; Henderson, supra note 7, at 346.

88. Traditionally, a promise in a writing under seal was enforceable without consideration. See FARNSWORTH, supra note 4, $\S 2.16$, at 86 ; Eisenberg, supra note 8 , at 8 . Like the $\S 90$ requirements of foreseeability, definiteness, and substantiality, the formality of a writing under seal serves a cautionary function by alerting the promisor to the seriousness of her promise. See FARNSWORTH, supra note 4, $\$ 2.16$, at 87; Eisenberg, supra note 8, at 8-9; Fuller, supra note 13, at 800 . 
For Williston and the First Restatement, it was not enough that the reliance be reasonably foreseeable; the expected action or forbearance also had to be "of a definite and substantial character."89 Subsequent critics find the language "definite and substantial" problematic, primarily because in their view the nature and degree of the promisee's reliance matters only in computing damages. ${ }^{90}$ Both requirements have been eliminated from the Second Restatement. Professor Braucher, the reporter for the Second Restatement, justified this change on the ground (among others) that "the requirement of reliance of a definite and substantial character becomes doubtful" with the addition of a second sentence in Section 90 allowing courts to limit the remedy awarded as justice requires. ${ }^{91}$

Once again, the critics proceed from a different perspective than Williston's and, not surprisingly, reach a different conclusion. If Section 90 is designed to protect reliance, they argue, there is no reason to require that the reliance be definite and substantial. Any reliance should be protected; if indefinite or insubstantial, it will be compensated accordingly..$^{92}$ But Williston's discussion of the language "definite and substantial" focused on the promisor, not on the promisee. For Williston, the requirements of definiteness and substantiality served not to mark the level of reliance that deserved protection, ${ }^{93}$ but to establish the level of foreseeable consequences that would justify holding the promisor to her promise:

[Definite and substantial] action should reasonably have been expected by the promisor .... [ []t will not be enough that some action of the

Other legal systems have adopted different methods for ensuring that a donative promise is well considered. Under German law, for example, a promise to make a gift becomes enforceable and irrevocable if the promise is notarized in a formal ceremony before a public official. Dawson, supra note 51, at 226. Like the requirements of $\S 90$, the German notarization procedure serves to ensure deliberation and informed assent by the promisor. See id.

89. See Commentaries, supra note 42 , at $20 ; 1926$ Proceedings, supra note 29 , at 90.

90. See 1A CORBIN, supra note $13, \S 200$, at 217 ("The more free and flexible the court is willing to be in determining the extent of the recovery, the more variation is made possible in applying such a requirement as that the action in reliance must be "substantial." "); Eisenberg, supra note 8, at 21-22 ("If a donative promisee's reliance is nontrivial ... how could the law justifiably refuse to enforce the promise, at least to the extent of the reliance?"); Fuller \& Perdue, supra note 8, at 420 ("This problem ... permits of a more rational answer ... . than to say, as Section 90 of the Restatement ... asks us to say: 'Either your losses must have been so great as to justify us in enforcing the whole promise, or you go without remedy." "). But see Knapp, supra note 5, at 59 ("In the light of the important policies underlying consideration and form, a court might well require ... that the plaintiff seeking enforcement demonstrate reliance that is both definite and substantial." (footnotes omitted)).

91. See Proceedings at Forty-second Annual Meeting, 42 A.L.I. PROc. 296 (1965) [hereinafter 1965 Proceedings]; see also CALAMARI \& PERLLO, supra note 8, \$ 6-1, at 273 (" $[P]$ remise of full recovery ... is probably the reason for including in [original § 90 ] the provisions for definite and substantial reliance.").

92. See CALAMARI \& PERILLO, supra note 8, § 6-1, at 273 (provision for flexible remedy contributed to omission of "definite and substantial" clause); Eisenberg, supra note 8, at 22 ("How could the law justifiably refuse to enforce the promise, at least to the extent of the reliance?").

93. The point in the text is demonstrated by Williston's insistence that even substantial reliance would not make a promise enforceable if the promisor did not reasonably foresee the particular action in reliance that resulted. See Commentaries, supra note 42, at 20: 1926 Proceedings, supra note 29, at 93. 
promisee, even if [of] substantial character[,] has been induced by the promise. ${ }^{94}$

[T] his section covers a case where there is a promise to give and the promisor knows that the promisee will rely upon the proposed gift in certain definite ways.

....

... The uncle should certainly expect that the next thing that would happen would be that Johnny would run around the corner to the Buick agency and get a car and perhaps sign some promissory notes for it.

We have confined the Section to the case where a reasonable person would say that the promisor expected the man to do just what he did or that he ought to have expected it. ${ }^{95}$

Because his objective was to enforce certain types of promises, not to protect reliance, Williston rejected the view that "any reliance on a gratuitous promise will render the promise enforceable . ."96 For Williston, the problem was to identify those promises that ought to be enforced. His solution was to require that the promisor reasonably expect her promise to induce action or forbearance of a definite and substantial character.

Of the two limitations, the more revealing is the requirement of definiteness. If solicitude for the promisee were the primary concern of Section 90, it would be hard to justify a requirement that the promisor foresee the particular act in reliance, ${ }^{97}$ as the word "definite" requires. ${ }^{98}$ Any reliance-or at least any nontrivial reliance-would be sufficient to justify requiring the promisor to compensate the promisee for the harm suffered. But requiring that the promisor foresee the particular act in reliance helps to ensure that Section 90 comes into play only when the seriousness of her promise was apparent to the promisor.

The requirement of substantiality may be read in the same vein: rather than justifying enforcement on the degree of a promisee's reliance, it helps instead to identify promises that the promisor understood might have serious conse-

94. Commentaries, supra note 42 , at 20.

95. 1926 Proceedings, supra note 29 , at $89,91,93$.

96. Id. at 93 (emphasis added); see also Commentaries, supra note 42 , at 20 ( $\$ 90$ "does not assert a sweeping rule that in every case action in reliance is sufficient support for a promise"); 1926 Proceedings, supra note 29, at 90 (remarks of Prof. Williston) ("[T]here is the danger that the inference will be drawn that wherever a promise is reasonably relied upon it becomes binding. That would go farther than Section [90].").

97. See Eisenberg, supra note 8 , at 22 ("If the promisee relied, and the promisor should reasonably have expected to induce reliance . . . how could the law justifiably refuse to enforce the promise on the ground that the promisor need not have expected the promisee to do 'just' what he did?").

98. See $1 \mathrm{~A}$ CORBIN, supra note $13, \S 200$, at 218 ("[T]he promisor must have had reason to foresee the definite action or forbearance that in fact followed."). 
quences..$^{99}$ A promisor is less likely to make a promise casually if she expects it to induce substantial action in reliance by the promisee.

Taken together, the words "definite and substantial" make clear what the language of the First Restatement accomplishes: If the promisor made a promise expecting it to induce action or forbearance of a definite and substantial character, the promise was likely well considered and deserving of legal enforcement. Thus, the "definite and substantial" clause in Section 90 of the First Restatement serves the same cautionary function that reciprocity serves in the context of bargains. ${ }^{100}$

During the American Law Institute proceedings on the Second Restatement, Braucher did not discuss this explanation for the requirements of definiteness and substantiality, ${ }^{101}$ and the fundamental change effected by deleting the "definite and substantial" clause was not fully appreciated. As a measure of the degree of the promisee's reliance, the words are unnecessary, as Braucher argued. That objective can be served quite easily by calibrating the amount of damages to reflect the nature and degree of reliance. But because the words "definite and substantial" actually serve to evaluate the quality of the promisor's commitment, their elimination from the Second Restatement is more problematic from a normative perspective than Braucher seemed to recognize. ${ }^{102}$

Braucher gave a second reason for dropping the requirements of definiteness and substantiality. Because courts often enforce marriage settlements and charitable subscriptions in the absence of definite and substantial reliance, it seemed necessary to drop those requirements. ${ }^{103}$ Still, the language of the

99. Williston did not expressly justify the substantiality requirement on the basis discussed in the text. But his repeated emphasis on the promisor rather than on the promisee shows that he was not primarily concerned with the degree of the promisee's reliance. Moreover, Williston discussed a hypothetical in which he would deny recovery despite substantial reliance by the promisee because the promisor reasonably did not expect that the promise would induce the action taken by the promisee. See 1926 Proceedings, supra note 29, at 93; see also Commentaries, supra note 42, at 20 ("II]t will not be enough that some action of the promisee, even if [of] substantial character[,] has been induced by the promise.").

100. But see Eisenberg, sipra note 8, at 18-19 ("The prospect of reliance may have a sobering effect on the promisor, but since the motive is donative rather than calculating, a significant danger remains that the promise was made without sufficient deliberation."). It is important to note again that the First Restatement required much more than a "prospect of reliance" for a $\S 90$ promise to be enforceable: the foreseen action (or forbearance) had to be both definite and substantial. The combined requirements of foreseeability, definiteness, and substantiality in the First Restatement certainly increase the likelihood that the promise was well considered, and the elimination of these requirements, which Professor Eisenberg advocates, see $i d$. at 20-23, is likely to increase the risk that the promise was impulsive and ill considered.

101. Braucher's failure to discuss this explanation may have been due to the fact that leading commentators read the "definite and substantial" language as marking the degree of reliance by the promisee that deserved legal protection. See, e.g., Fuller \& Perdue, supra note 8 , at 402 ("[T] he reliance must be so 'definite and substantial' as to justify an enforcement of the whole promise.").

102. It is also problematic in a descriptive sense, for the definite and substantial requirements still generally reflect the reported cases. See cases cited infra note 344. For criticism of the decision to drop the "definite and substantial" clause, see Knapp, supra note 5, at 58-59; see also MURRAY, supra note 16, § $66(B)(1)$, at 280 (new provision raises troublesome issue of whether court should enforce promise if reliance is indefinite and insubstantial).

103. See 1965 Proceedings, supra note 91, at 289, 297. 
First Restatement is not wrong: a promise that meets its criteria is "binding," as the section states. The problem with the First Restatement is that it does not go far enough. Charitable subscriptions are sometimes enforced even when the promisor did not contemplate definite and substantial reliance. ${ }^{104}$

The more interesting and fundamental question is whether the enforcement of nonbargain promises is based on reliance or on promise. The weakness of reliance theory is demonstrated by a revealing exchange at the American Law Institute proceedings on the Second Restatement. After Braucher gave his reasons for dropping the words "definite and substantial," a member of the audience pointed out that in the contexts of marriage settlements, charitable subscriptions, and other gifts, courts often do not require any reliance whatsoever. ${ }^{105} \mathrm{He}$ proposed, therefore, that Section 90 be revised to reflect the absence of a requirement of actual reliance in the cases. ${ }^{106}$ Braucher conceded that there was a "certain fictitious quality" about the reliance in the cases and thought the proposal "worth consideration." 107 The result of further deliberations was the addition of a second subsection providing that "[a] charitable subscription or a marriage settlement is binding ... without proof that the promise induced action or forbearance." 108

This subsection was an admission that reliance was not the basis for enforcing at least some Section 90 promises. ${ }^{109}$ The new subsection also revealed that elimination of the "definite and substantial" clause was neither sufficient nor necessary to deal with the very cases that prompted the change. The addition of this subsection left no reason to drop the requirements of definiteness and substantiality in subsection $1^{110}$ (other than the mistaken view that those requirements serve to mark the level of reliance that deserves protection). So long as charitable subscriptions and marriage settlements are governed by the separate rule of subsection $2,{ }^{111}$ Williston's original formula continues to work quite well. Virtually every case in which a promise is enforced under subsection 1 involves a promisor who should reasonably foresee particular, substantial action (or forbearance) in reliance on the promise. ${ }^{112}$

104. See infra notes $348-49$ and accompanying text.

105. See 1965 Proceedings, supra note 91, at 297 (remarks of Mr. Boskey).

106. See id.

107. Id. at 298 (remarks of Prof. Braucher); see also id. at 289 ("Reliance of a largely fictitious character is upheld in many cases.").

108. RESTATEMENT (SECOND) OF CONTRACTS $\$ 90(2)$ (1981).

109. See infra text accompanying notes 287-92.

110. Cf. Knapp, supra note 5 , at 59 n. 50 ("Now that charitable cases are dealt with separately ... there is even less reason to suggest that in ordinary cases under $\$ 90$ the court should be indifferent to the definite or substantial character of the plaintiff's action in reliance.").

111. Unlike charitable pledges, marriage settlements arguably satisfy the foreseeability requirements of the First Restatement because the promisor may foresee that the promisee might change her behavior in reliance on the settlement. Although the promisee need not prove that the promise induced an actual change of position, this is equally true of other subsection 1 promises. See infra text accompanying notes 287-312.

112. See cases cited infra note 344 . 
The changes in the Second Restatement reflect a reliance-based view of Section 90 that differs considerably from the promissory conception of the First Restatement. The remainder of this Article establishes that the reported cases support the First Restatement. This conclusion suggests that the drafters of the Second Restatement, and reliance theorists generally, failed to heed the lessons of legal realism. Realists have argued that courts should decide cases to further social policies. They also have argued that courts in fact decide cases on that basis, rather than on the basis of abstract doctrine. ${ }^{13}$ In the context of Section 90 , reliance advocates have overlooked the second point. Upon identifying reliance as the reason for enforcing Section 90 promises, they have criticized Williston (and implicitly the courts) as a rigid formalist for endorsing outcomes that do not conform to reliance theory. But if courts decide cases on the basis of policy rather than doctrine, it is important to identify the policy that motivates courts in Section 90 cases. We find that courts respond to a policy of enforcing serious promises.

\section{THE REMEDY FOR BREACH OF A SECTION 90 PROMISE}

[A]s frequently happens in promissory estoppel cases, the value of the plaintiff's detrimental reliance need not be identical with, or equated to, the value of the defendant's promise. The cases hold that the appropriate remedy lies in the enforcement of the defendant's promise. The promise here ... consisted of the defendant's commitment that it stood liable under the policy for the amount of the judgment against the plaintiff. The measure of damages must therefore be the amount of the judgment. ${ }^{114}$

This passage from a California opinion evidences what Williston discovered and reported in the 1920's: the remedy routinely granted in Section 90 cases is enforcement of the promise either by expectation damages or by specific performance. The passage also supports Williston's simple explanation: for breach of promise, the proper remedy is to put the promisee in the same position in which she would have been had the promise been kept.

The Second Restatement and an array of academic commentators disagree with Williston and the California opinion. ${ }^{115}$ They argue that a reliance measure of damages is appropriate in Section 90 cases because the promisee's right of action is founded on detrimental reliance. In support of that proposition, they

113. See JEROME FRANK, LAW AND THE MODERN MIND 166-67 (1930); Llewellyn, supra note 19; A.W.B. Simpson, The Rise and Fall of the Legal Treatise: Legal Principles and the Forms of Legal Literature, 48 U. CHI. L. REv. 632, 677-78 (1981). These statements about legal realism must be understood with the caveat that generalizations about the views of all realists are risky. See Llewellyn, supra note 19 , at $1233-34,1254-56$.

114. Tomerlin v. Canadian Indem. Co., 394 P.2d 571, 578 (Cal. 1964).

115. See infra text accompanying notes 164-78. 
proffer cases in which courts awarded reliance damages for claims based on Section 90 .

This part examines the cases and concludes, with Williston, that the remedy routinely granted is either specific performance or expectation damages. Those rare instances in which courts award reliance damages involve either a problem with the promise or a difficulty in assessing expectation damages. ${ }^{116}$ Some courts (like the California Supreme Court in the quoted passage) explain an expectancy measure by expressly tying the remedy to the promise; ${ }^{117}$ more often, courts grant specific performance or expectation damages without analysis or discussion. ${ }^{118}$ That courts enforce promises rather than compensate reliance under Section 90 is powerful evidence that the basis of the section in the courts is promise.

\section{A. Expectation is the Routine Remedy under Section 90}

\section{The Reported Cases}

Although the Second Restatement of Contracts sanctions reliance as the measure of recovery in Section 90 cases, the cases it cites in explaining Section 90 reveal that expectation is the normal measure of relief. The reporter's note references twenty-nine cases in which the promisee was afforded relief; ;19 twenty-four cases that awarded expectancy relief in the form of specific performance, expectation damages, or an injunction; ${ }^{120}$ and only five cases

116. When expectation damages are difficult to prove, courts often grant specific performance or an injunction to ensure the promisee the benefit of the bargain. See EDWARD YORIO, CONTRACT ENFORCEMENT: SPECIFIC PERFORMANCE AND INIUNCTIONS $\$ 2.4$, at 36-37 (1989) (difficulty of proving damages is reason to grant equitable relief). However, in the cases discussed infra in which reliance damages were awarded under $\$ 90$ because expectation damages were not provable, specific performance also could not be granted because the promise was too indefinite to be specifically enforced, see infra text accompanying notes 233-34, 242-43, or because the type of contract at issue was not specifically enforceable for reasons of public policy. See YORIO, supra, \$14.4, at 378-79 (employment contracts generally not specifically enforceable against employer); see also infra text accompanying notes 266-68 (discussion of cases involving employment promises). Some of the cases involved employment contracts terminable at will, in which specific performance would be futile in any event because the employer might terminate the employment shortly after the equitable decree issues. See YORIO, supra, $\S 5.5$ (court will not order specific performance when promisor has right of termination under contract).

117. See, e.g., Katz v. Danny Dare, Inc., 610 S.W.2d 121 (Mo. Ct. App. 1980).

118. See, e.g., Greiner v. Greiner, 293 P. 759 (Kan. 1930); Feinberg v. Pfeiffer Co., 322 S.W.2d 163 (Mo. Ct. App. 1959).

119. RESTATEMENT (SECOND) OF CONTRACTS $\S 90$ reporter's note (1981); see cases cited infra notes 120-21. In the remaining cases cited in the reporter's note, the courts refused to grant any relief. See infra cases cited in notes $325-29$.

120. See D'Oench, Duhme \& Co. v. FDIC, 315 U.S. 447 (1942) (specific performance of note); Janke Constr. Co. v. Vulcan Materials Co., 386 F. Supp. 687 (W.D. Wis. 1974) (expectation damages), aff'd, 527 F.2d 772 (7th Cir. 1976); Crail v. Blakely, 505 P.2d 1027 (Cal. 1973) (same); Burgess v. California Mut. Bldg. \& Loan Ass'n, 290 P. 1029 (Cal. 1930) (same); Graddon v. Knight, 292 P.2d 632 (Cal. Dist. Ct. App. 1956) (same); Chrysler Corp. v. Quimby, 144 A.2d 123 (Del. 1958) (same); Salsbury v. Northwestern Bell Tel. Co., 221 N.W.2d 609 (Iowa 1974) (same); Miller v. Lawlor, 66 N.W.2d 267 (Iowa 1954) (injunction); Greiner v. Greiner, 293 P. 759 (Kan. 1930) (specific performance); Devecmon v. Shaw, 14 A. 464 (Md. 1888) (expectation damages); McLearn v. Hill, 177 N.E. 617 (Mass. 1931) (specific performance of implied 
that awarded reliance damages or restitution. ${ }^{121}$ In the few cases granting a nonexpectancy measure of relief, an award of expectation damages was inappropriate for one of the following reasons: there was no promise; the alleged promise was not proved; the case was decided under a legal principle different from breach of promise; or, expectation damages were difficult to prove. ${ }^{122}$

Recent surveys confirm that expectancy is the routine measure of relief in Section 90 cases. ${ }^{123}$ A 1984 canvass of cases decided during the preceding fifteen years found that the typical monetary remedy was expectation damages and that specific performance was granted whenever it would have been available in a comparable cause of action involving a bargain. ${ }^{124} \mathrm{~A} 1985$ survey of every case in the preceding ten years that cited Section 90 of either Restatement found that five-sixths of the cases that addressed the issue of the extent of recovery granted full expectation relief and only one-sixth limited recovery to reliance damages. ${ }^{125}$ A 1987 article concluded that courts routine-

promise not to plead statute of limitations); Huhtala v. Travelers Ins. Co., 257 N.W.2d 640 (Mich. 1977) (defendant's promise specifically enforced to preclude statute-of-limitations defense); Lusk-Harbison-Jones, Inc. v. Universal Credit Co., 145 So. 623 (Miss. 1933) (plaintiff's promise specifically enforced to preclude recovery); Feinberg v. Pfeiffer Co., 322 S.W.2d 163 (Mo. Ct. App. 1959) (expectation damages); Ricketts v. Scothorn, 77 N.W. 365 (Neb. 1898) (same); Horsfield v. Gedicks, 118 A. 275 (N.J. Ch. 1922) (specific performance), aff $d$ mem., 124 A. 925 (N.J. 1924); Spiegel v. Metropolitan Life Ins. Co., 160 N.E.2d 40 (N.Y. 1959) (expectation damages); Siegel v. Spear \& Co., 138 N.E. 414 (N.Y. 1923) (same); De Cicco v. Schweizer, 117 N.E. 807 (N.Y. 1917) (same); Phalen v. United States Trust Co., 78 N.E. 943 (N.Y. 1906) (specific performance); Hamer v. Sidway, 27 N.E. 256 (N.Y. 1891) (expectation damages); Spector v. National Cellulose Corp., 48 N.Y.S.2d 234 (Sup. Ct. 1943) (promise by plaintiff not to collect on note specifically enforced), aff' $d, 47$ N.Y.S. 2d. 311 (App. Div. 1944); In re Field's Estate, 172 N.Y.S.2d 740 (Sur. Ct. 1958) (oral charitable subscriptions valid and enforceable); East Providence Credit Union v. Geremia, 239 A.2d 725 (R.I. 1968) (expectation damages).

121. See Goodman v. Dicker, 169 F.2d 684 (D.C. Cir. 1948) (reliance damages); Terre Haute Brewing Co. v. Dugan, 102 F.2d 425 (8th Cir. 1939) (same); Kaufman v. Miller, 214 Ill. App. 213 (1919) (restitution); Aiello v. Knoll Golf Club, 165 A.2d 531 (N.J. Super. Ct. App. Div. 1960) (reliance damages); Hoffman v. Red Owl Stores, 133 N.W.2d 267 (Wis. 1965) (same).

122. See infra text accompanying notes 183-94, 209-23, 231-34, 237-43.

123. See sources cited supra note 16.

124. See Feinman, supra note 7 , at $679,687-88$.

125. See Farber \& Matheson, stupra note 16, at $907,909$.

We have been unable to obtain either from the authors or from the publisher a list of the approximately 12 cases in which the plaintiff recovered reliance damages. We are aware of nine cases decided during the period of the survey (1975-85) in which reliance damages were awarded or made available on remand. See Nimrod Mktg. (Overseas) Ltd. v. Texas Energy Inv. Corp., 769 F.2d 1076 (Sth Cir. 1985); Green v. Interstate United Mgt. Serv. Corp., 748 F.2d 827 (3d Cir. 1984); Werner v. Xerox Corp., 732 F.2d 580 (7th Cir. 1984); Hunter v. Hayes, 533 P.2d 952 (Colo. Ct. App. 1975); Baxter's Asphalt \& Concrete, Inc. v. Liberty County, 406 So. 2d 461 (Fla. Dist. Ct. App. 1981); Ravelo ex rel. Ravelo v. County of Haw., 658 P.2d 883 (Haw. 1983); State Mechanical Contractors, Inc. v. Village of Pleasant Hill, 477 N.E.2d 509 (IIl. App. Ct. 1985); Grouse v. Group Health Plan, 306 N.W.2d 114 (Minn. 1981); Stacy v. Merchants Bank, 482 A.2d 61 (Vt. 1984).

These cases in no way evidence a preference on the part of the deciding court for reliance damages. Rather, reliance damages were awarded in eight of the cases because: (1) the plaintiff did not seek expectation damages (Nimrod, Hunter, Stacy); (2) the promise was defective or unproven (Green); (3) expectation damages were difficult to measure (Ravelo, Grouse); or (4) the wrong on the part of the defendant was not a breach of promise so much as a violation of its bid procedures (Baxter's, State Mechanical). The opinion in Werner does not reveal whether the plaintiff sought expectation damages under $\$ 90$. Seven of these cases are discussed below in some detail. See infra notes $267-72$ and accompanying text. It seems likely that reasons similarly consistent with a promissory theory of $\S 90$ may explain the award of reliance damages 
ly award expectancy relief. ${ }^{126}$ In cases of donative promises, the remedy is specific performance or expectation damages; in cases of commercial promises, the remedy is expectation damages unless speculative or otherwise unavailable under the normal limitations on contract damages. ${ }^{127}$

\section{Explanations for the Prevalence of Expectancy Relief}

These surveys strongly suggest that courts proceed from the assumption that the appropriate remedy for breach of a Section 90 promise is to put the promisee in the same position in which she would have been had the promise been kept. But the idea that reliance is the appropriate measure of recovery under Section 90 is so ingrained in the academic culture that commentators seem compelled to find nonpromissory explanations for the prevalence of expectancy relief. ${ }^{128}$ Some of these explanations are ad hoc rationalizations that need not be addressed textually. ${ }^{129}$ Others have a superficial plausibility belied by plainly inconsistent cases. All of the explanations share an almost total lack of support in the opinions: ${ }^{130}$ courts enforce promises by specific

in the other cases.

126. See Becker, supra note 16 , at 135 .

127. See id at 134-35. Studies focusing on decisions from a particular jurisdiction confirm that expectancy is the routine measure of relief. See Note, C \& K Engineering Contractors v. Amber Steel Co.: Promissory Estoppel and the Right to Trial by Jury in California, 31 HASTnGS L.J. 697, 715 (1980) (in California, courts award expectation damages for breach of $\$ 90$ promise).

128. See infra text accompanying notes $132-35,139-42$.

129. Consider, for example, explanations offered for promises to give land to a family member. If the promisee relies on the promise by making improvements on the property, courts typically grant specific performance upon the promisor's refusal to transfer title. See sources cited infra note 149. Dean Boyer suggests the following reasons, among others, for the availability of specific performance: courts "are inclined to treat questions of the relief to be afforded as mere details of procedure"; courts may not be "aware of restitution as an alternate remedy"; and "enforcement of the promise, not just restoration of the status quo, is the normal remedy in equity." Benjamin F. Boyer, Promissory Estoppel: Principles from Precedents (pt. 1), 50 MiCH. L. REV. 639, 663-64 (1952). Describing a choice between specific performance and restitution as a "mere detail of procedure" is strange since the difference between the value of the land and the value of the improvement-the measure of recovery in restitution-is likely to be substantial. That courts are aware of remedial alternatives to specific performance is evidenced by decisions limiting recovery to amounts expended in reliance or to restitution measured by the value of the improvements when proof of a promise is lacking. See, e.g., Kaufman v. Miller, 214 Ill. App. 213 (1919) (restitution of value of improvements); Aiello v. Knoll Golf Club, 165 A.2d 531, 536 (N.J. Super. Ct. App. Div. 1960) (damages measured by amounts expended in reliance). Although courts of equity often granted specific performance, they always had available an alternate restitutionary remedy in the form of an equitable accounting that would require the defendant merely to disgorge the value of any benefit received rather than to perform specifically. See 1A CORBIN, supra note 13, \$ 205, at 236; 1 GEORGE E. PALMER, THE LAW OF RESTITUTION $\S 1.5(\mathrm{c})$, at $24-29$ (1978). When a promise had not been proven by competent evidence, equity in fact limited recovery to the value of the improvements pursuant to the remedy of an accounting. See, e.g., Kauffman.

130. A couple of opinions incorporate reliance-based explanations for the prevalence of expectancy relief. See Goldstick v. ICM Realty, 788 F.2d 456, 463 (7th Cir. 1986) (Posner, J.) ("There is much to be said for using the value of the promise as the measure of damages, simply on grounds of simplicity."); Sullivan v. O'Connor, 296 N.E. 183, 188 (Mass. 1973) (Kaplan, J.) (arguments for an expectancy measure "are at their strongest when the promises are made in a business context ... [and] become weaker as the context shifts from a commercial to a noncommercial field"). It is telling that these opinions were written by former law school professors who might be more receptive than other judges to the arguments of 
performance, expectation damages, or an injunction, without relying on (or even mentioning) any of the nonpromissory explanations for expectancy relief proffered by the academic commentators. ${ }^{131}$

One common explanation links the prevalence of expectancy relief to expansion of the ambit of Section $90{ }^{132}$ Originally conceived as a vehicle for enforcing donative promises, Section 90 now is often used to enforce commercial promises. ${ }^{133}$ Commentators argue that the reasons for awarding expectation damages for breach of a commercial bargain lead courts to grant identical relief for a commercial claim under Section 90: expectancy relief promotes beneficial economic activity ${ }^{134}$ or compensates for opportunities foregone in reliance on the transaction with the promisor. ${ }^{135}$

This explanation for the prevalence of expectancy relief is seriously flawed. Section 90 originated precisely because courts were enforcing promises outside the commercial context in the absence of a bargain. The early cases on which the section was based delivered a critically important message: a promise may be enforced even if it does not further the process of economic exchange. Moreover, these early cases granted expectancy relief even though a donative promisee generally does not forego other opportunities. ${ }^{136}$ The early history of Section 90 thus belies the suggestion that courts award expectation damages to further economic activity or to compensate for foregone opportunities. Recent surveys also establish that expectancy relief is routinely granted in cases of purely donative promises. ${ }^{137}$ Of the twenty-four cases cited in the Second Restatement in which the promisee obtained expectancy relief under Section 90 , eleven involved donative promises. ${ }^{138}$

academic commentators.

131. For example, none of the cases cited by the Second Restatement relies on a nonpromissory explanation for granting expectancy relief. See cases cited supra note 120.

132. See Feinman, supra note 7, at 688 ("One explanation for the prevalence of expectation damages is a shift in the nature of the cases that constitute the bulk of promissory estoppel litigation, a shift from cases of donative promise to cases involving business exchanges."); Henderson, supra note 7, at 378-79 ("[T]he cases which use Section 90 as the ground for awarding the promised performance typically involve bargain transactions."); Comment, stupra note 35, at 563 ('The propriety of the results dictated by a rule limiting reimbursement to out-of-pocket expenditures declined as the use of promissory estoppel expanded into commercial settings.").

133. See Becker, supra note 16, at 132 ("expansion of promissory estoppel to commercial settings"); Farber \& Matheson, supra note 16, at 907 ("Promissory estoppel is regularly applied to the gamut of commercial contexts."); Feinman, supra note 7, at 688 ("shift in the nature of the cases that constitute the bulk of promissory estoppel litigation, a shift from cases of donative promise to cases involving business exchanges"); Henderson, supra note 7, at 344 ("The usual setting out of which a Section 90 promise currently emerges ... is commercial, not benevolent. More important, the promise which calls for application of Section 90 is typically one which contemplates an exchange.").

134. See Farber \& Matheson, supra note 16, at 929-30.

135. See MURRAY, supra note $16, \S 66(\mathrm{~B})(3)$, at 284; Feinman, supra note 7, at 688 ; Comment, supra note 35 , at 566-70.

136. See supra text accompanying note 56.

137. See, e.g., Becker, supra note 16, at 134-35, 154, 163; see also MURRAY, supra note 16, $\S 66(\mathrm{~B})(3)$, at 283.

138. See Crail v. Blakely, 505 P.2d 1027 (Cal. 1973) (intrafamily donative promise); Salsbury v. Northwestern Bell Tel. Co., 221 N.W.2d 609 (Iowa 1974) (charitable subscription); Miller v. Lawlor, 66 
Another common explanation for the prevalence of expectancy relief is based on the difficulty of proving the amount of the reliance loss in many cases: ${ }^{139}$ the promisee may have suffered a nonquantifiable personal loss ${ }^{140}$ or may have incurred unprovable opportunity costs. ${ }^{141}$ Commentators argue that expectation damages in these circumstances are the best available surrogate for compensating for a reliance loss. ${ }^{142}$

This explanation works reasonably well when reliance damages are difficult or impossible to calculate. As a general theory, however, it would be persuasive only if courts were to opt for reliance damages in cases presenting a choice between readily calculable expectation and reliance damages. ${ }^{143}$ The reported cases demonstrate the contrary: when they have a choice, courts choose expectation. ${ }^{144}$ Chrysler Corp. v. Quimby ${ }^{145}$ presented a clear choice between awarding a specific amount of reliance damages and awarding that amount plus expectation damages measured by lost profits. The court granted the higher amount. In Ricketts $v$. Scothorn, ${ }^{146}$ the plaintiff gave up employment at $\$ 10$ a week in reliance on her grandfather's written promise in the form of a note for $\$ 2,000$ plus interest. Approximately a year later, she resumed employment with her grandfather's permission. At the time of his death, the note had not been paid, and his administrator reneged on the promise. The court had a clear choice between compensating the plaintiff for income lost during the year of her unemployment (approximately $\$ 520$ ) or awarding the value of the note $(\$ 2,000$ plus interest). The court awarded expectancy relief by enforcing the note. In Estate of Bucci, ${ }^{147}$ the defendant's testator agreed to give the plaintiff

N.W.2d 267 (Towa 1954) (gratuitous promise of neighbor); Greiner v. Greiner, 293 P. 759 (Kan. 1930) (intrafamily donative promise); Devecmon v. Shaw, 14 A. 464 (Md. 1888) (same); Ricketts v. Scothorn, 77 N.W. 365 (Neb. 1898) (same); Horsfield v. Gedicks, 118 A. 275 (N.J. Ch. 1922) (same), aff'd mem., 124 A. 925 (N.J. 1924); De Cicco v. Schweizer, 117 N.E. 807 (N.Y. 1917) (same); Phalen v. United States Trust Co., 78 N.E. 943 (N.Y. 1906) (charitable subscription); Hamer v. Sidway, 27 N.E. 256 (N.Y. 1891) (intrafamily donative promise); In re Field's Estate, 172 N.Y.S.2d 740 (Sur. Ct. 1958) (charitable subscription).

139. See FARNSWORTH, supra note $4, \S 2.19$, at 101 ("To the extent that calculation of the reliance measure is complicated by difficulty in valuing the detriment, recovery of the expectation interest is likely.").

140. See Eisenberg, supra note 8, at 26-30.

141. See MURRAY, supra note $16, \S 66(B)(3)$, at 284; Becker, supra note 16 , at 139 ; Boyer, supra note 8, at 486; Eisenberg, supra note 8, at 26-30; Metzger \& Phillips, supra note 8, at 544; Comment, supra note 35 , at $566-70$.

142. See MURRAY, supra note $16, \S 66(B)(3)$, at 284; Becker, supra note 16 , at 139 ; Boyer, supra note 8, at 486; Eisenberg, supra note 8, at 26-30; Metzger \& Phillips, supra note 8, at 544; Comment, supra note 35, at 569-70; cf.Fuller \& Perdue, supra note 8, at 67 ("For reasons of convenience and certainty the court may choose a measure of recovery which differs from that suggested by the interest protected.").

143. See Fuller \& Perdue, supra note 8 , at $69-70$ ("[I]f in cases coming under $\$ 90$ the expectation interest is preferred as a measure of recovery merely for its certainty, then we might expect to see substituted for it the reliance interest in every case in which that interest happened to offer a relatively certain standard for computing damages.").

144. See Becker, supra note 16 , at 154 ("Expectation damages are also generally available, even when reliance damages could easily be calculated.").

145. 144 A.2d 123 (Del. 1958). For a fuller exposition and discussion of the facts, see infra text accompanying notes 197-207.

146. 77 N.W. 365 (Neb. 1898).

147. 488 P.2d 216 (Colo. Ct. App. 1971). 
$\$ 17,000$ toward the purchase of property. Relying on the promise, the plaintiff purchased an option on the property for $\$ 2,000$. When the defendant reneged, the plaintiff sued and succeeded in recovering $\$ 17,000$ in damages-the value of the promise-even though an award of $\$ 2,000$ (the cost of the option) would have protected her reliance interest. ${ }^{148}$

Courts often face a clear choice between specific performance and reliance damages (or restitution) in cases involving improvements made to land. In the typical case, a promise is made to give a family member a parcel of real estate. The promisee then makes improvements on the property, and the promisor reneges. These facts present several remedial alternatives: reliance damages measured by the amount the promisee expended improving the land; restitution measured by the value of the improvements to the promisor; or specific performance. Courts routinely grant specific performance. ${ }^{149}$ Difficulty in calculating reliance damages or restitution does not explain this outcome, for courts find it easy to calculate and award reliance damages or restitution when the plaintiff fails to prove that a promise was in fact made. ${ }^{150}$ While in some cases a change in location or lifestyle by the promisee may constitute a nonquantifiable reliance loss, ${ }^{151}$ courts grant specific performance in other cases in which the promisee continued to live in the same area and actually benefitted from rent-free use of the property before the promisor repudiated. ${ }^{152}$ Even when the plaintiff demonstrably suffered no reliance loss at all because the value of rent-free use of the land exceeded the cost of the improvements, specific performance is granted. ${ }^{153}$ In light of the disparity between reliance damages and expectancy relief in these cases, ${ }^{154}$ courts would limit the promi-

148. Commentators have argued that expectancy relief may be preferred because it is simpler to administer than reliance damages. See Becker, supra note 16, at 140; Fuller \& Perdue, supra note 8, at 66; Comment, supra note 35, at 570-71. Other commentators have suggested that the equivalence of expectation and reliance damages in many cases makes the choice unimportant. See Farber \& Matheson, supra note 16, at 909 n.24; Fuller \& Perdue, supra note 8, at 73, 405. The outcome in cases like Chrysler, Ricketts, and $B u c c i$ belies both arguments: expectation damages are awarded even when reliance damages are as simple to administer and significantly lower in amount.

149. See, e.g., Wadsworth v. Hannah, 431 So. $2 d 1186$ (Ala. 1983); Greiner v. Greiner, 293 P. 759 (Kan. 1930); Horsfield v. Gedicks, 118 A. 275 (N.J. Ch. 1922), aff'd mem., 124 A. 925 (N.J. 1924); Young v. Overbaugh, 39 N.E. 712 (N.Y. 1895); Wells v. Davis, 14 S.W. 237 (Tex. 1890); see also CALAMARI \& PERILLO, supra note $8, \S 6-2(\mathrm{~b})$, at 276 ("Courts of equity in almost all states . . . have granted the promisee specific performance."); MURRAY, stpra note $16, \S 66(\mathrm{~A})(2)$, at 275 ("Promisee will succeed in a suit for specific performance of the promise to convey the land."); Shattuck, supra note 8, at 919 (the promisee "will get the land even though it be worth many times the amount of his total outlay.").

150. See, e.g., Kauffman v. Miller, 214 Ill. App. 213 (1919) (restitution); Aiello v. Knoll Golf Club, 165 A.2d 531 (N.J. Super. Ct. App. Div. 1960) (reliance damages). For a discussion and rejection of other explanations for the routine availability of specific performance in this context, see supra note 129.

151. See, e.g., Greiner v. Greiner, 293 P. 759 (Kan. 1930) (promisee uprooted himself from homestead); Boyer, supra note 8 , at 486.

152. See, e.g., Horsfield v. Gedicks, 118 A. 275 (N.J. Ch. 1922), aff' $d$ mem., 124 A. 925 (N.J. 1924); Wells v. Davis, 14 S.W. 237 (Tex. 1890).

153. See Young v. Overbaugh, 39 N.E. 712 (N.Y. 1895).

154. See Shattuck, supra note 8, at 919 ("The land [may] . . . be worth many times the amount of [the promisee's] total outlay."). 
see's recovery to reliance damages if their objective was to protect reliance rather than to enforce promises. ${ }^{155}$

\section{Flexibility of Remedies Under Section 90}

Several commentators suggest that courts take a flexible approach to remedies in Section 90 cases. ${ }^{156}$ Some read the Second Restatement-in particular the language allowing courts to limit the remedy as justice requires-as an endorsement of remedial flexibility. ${ }^{157}$ The commentators identify several reasons to limit the promisee to reliance damages, including: good faith on the part of the promisor, ${ }^{158}$ disparity between the value of the promise and the cost of reliance, ${ }^{159}$ ease of measuring the reliance loss, ${ }^{160}$ and difficulty in calculating expectation damages. ${ }^{161}$

The claim for remedial flexibility sometimes goes beyond the normative argument that courts ought to devise flexible remedies to the descriptive proposition that courts have in fact adopted a flexible approach to remedies in Section 90 cases. ${ }^{162}$ The reported cases, however, do not support this proposition. ${ }^{163}$ Expectancy relief is granted in the overwhelming majority of cases. Moreover, as the following materials show, of the factors identified by proponents of flexibility as justifying reliance damages, only a difficulty in calculating expectation damages explains cases that award reliance, and this use of reliance merely represents a concession by courts to practical necessity, not a preference for remedial flexibility. The only other factor that may lead a court to grant reliance damages is a defect in the promise or in proof of the promise.

155. See id. at 924 ("To accord with the purpose for which the action is allowed, the relief granted to the promisee should be a judgment or decree which reimburses him for the expenditures induced by the promise.").

156. See CAlAMARI \& PeRIllo, supra note $8, \S 6-6$, at 290-91; 1A CoRBIN, supra note 13 , $\$ 205$, at 240; FARNSWORTH, supra note 4, \$ 2.19, at 100-02; Fuller \& Perdue, supra note 8, at 405; Metzger \& Phillips, supra note 8, at 545; Comment, supra note 32, at 564 .

157. See Calamari \& Perillo, supra note 8, § 6-6, at 291; FARNsworth, supra note $4, \S 2.19$, at 99-101.

158. See FARNSwORTH, supra note $4, \S 2.19$, at 100-01 (lack of good faith on the part of the promisor may justify expectation damages); Metzger \& Phillips, supra note 8, at 500 ("Recovery of lost profits . . . may depend on the promisor's culpability.").

159. See CALAMARI \& PERILlo, supra note $8, \S 6-6$, at 291; IA CoRBIN, supra note 13, § 205; FARNSWORTH, supra note $4, \S 2.19$, at 101 .

160. See FARNSWORTH, supra note $4, \S 2.19$, at 101 . 101.

161. See CALAMARI \& Perillo, supra note $8, \S 6-6$, at 291 ; FARNsworth, supra note $4, \S 2.19$, at

162. See CALAMARI \& PERILLo, supra note 8, § 6-6, at 290-91; Fuller \& Perdue, supra note 8, at 405; Metzger \& Phillips, supra note 8 , at 545.

163. See MURRAY, supra note $16, \S 66(B)(3)$, at 283 ("[W] confronted the flexible remedy issue, it is clear that the typical recovery protects the expectation interest."); Feinman, supra note 7, at 687 ("[T]he current case law demonstrates that the remedial flexibility once attributed to promissory estoppel, if it ever existed, has been replaced by the application of remedies similar to those available in bargain cases."); Paul T. Wangerin, Damages for Reliance Across the Spectrum of Law: Of Blind Men and Legal Elephants, 72 IOWA L. REV. 47, 91-92 (1986) ("[J]udicial acceptance of the flexible damages remedy . . . has been, at most, nominal."). 
Rather than exhibiting flexibility, the reported cases actually demonstrate that courts operate within a remedial straightjacket: so long as a promise is proven and expectancy relief is feasible, the promisee is put in the same position in which she would have been had the promise been kept.

\section{B. Reliance Damages Are Awarded Only in Anomalous Cases}

Unlike judges deciding Section 90 cases, commentators have long resisted the idea that the proper measure of relief is expectancy. As early as the 1926 American Law Institute proceedings on the First Restatement, Professor Williston failed to convince members of the audience of the propriety of expectancy relief. In 1932, Professor Gardner argued that the remedy for breach of a Section 90 promise should be limited to compensation for loss suffered in reliance. ${ }^{164}$ Four years later Fuller and Perdue, after quoting extensively from Williston's remarks at the 1926 proceedings, argued that the reasons for awarding expectation damages for breach of promises arising in commercial contexts do not extend to gratuitous promises. ${ }^{165}$ Almost contemporaneously, Professor Shattuck argued that recovery should be restricted to reliance damages because the basis of the promisee's claim is injurious reliance on the promise. ${ }^{166}$

In the early 1950's, Section 90 was examined in a number of articles that presumed that the purpose of the section was to protect reliance by the promisee. ${ }^{167}$ From that premise, the authors concluded that reliance damages were the theoretically correct measure of relief in Section 90 cases. ${ }^{168}$ These articles helped lead the drafters of the Second Restatement to shape Section 90 in terms of reliance. ${ }^{169}$

The most obvious effect of the academic assault on expectancy relief is the addition of language to Section 90 which allows courts to limit the remedy as justice requires. This language is intended to sanction the use of reliance damages in Section 90 cases. ${ }^{170}$ Comment (a) to the new section asserts that

164. See George K. Gardner, An Inquiry into the Principles of the Law of Contracts, 46 HARV. L. REV. 1, 22-23 (1932).

165. Fuller \& Perdue, supra note 8, at 64-66.

166. See Shattuck, supra note 8 , at 941-45.

167. See Boyer, supra note 129; Boyer, supra note 8; Seavey, supra note 8.

168. See Boyer, supra note 8, at 487; Seavey, supra note 8, at 926.

169. See FARNSWORTH, supra note $4, \$ 2.19$, at 96 n.27. The articles by Boyer and Seavey are cited along with the articles by Fuller and Perdue and Shattuck in the reporter's note following $\$ 90$ and in comment (a) of that section. See RESTATEMENT (SECOND) OF CONTRACTS $\$ 90$ reporter's note, cmt. a (1981).

170. See RESTATEMENT (SECOND) OF CONTRACTS $§ 90$ reporter's note (1981); 1965 Proceedings, supra note 91, at 296-97 (remarks of Prof. Braucher); Eisenberg, supra note 8, at 26; cf. Knapp, supra note 5, at 55 (language permitting remedy to be limited "is ... a response to numerous writers over the years who have differed with Professor Williston's assertion that a promise enforced under section $90 \ldots$ must be enforceable ... to the full extent of the promised expectation"). 
reliance is a principal basis for enforcing promises even in the context of a bargain, ${ }^{171}$ and comment (d) goes on to state:

[T] he same factors which bear on whether any relief should be granted also bear on the character and extent of the remedy. In particular, relief may sometimes be limited ... to damages or specific relief measured by the extent of the promisee's reliance rather than by the terms of the promise. ${ }^{172}$

The preceding discussion shows that the Second Restatement moves significantly towards making reliance the appropriate measure of relief in Section 90 cases. ${ }^{173}$ If reliance is the basis for enforcing Section 90 promises (as comment (a) indicates), and if the remedy is to be linked to the reason for judicial intervention (as comment (d) indicates), it follows that reliance damages are an appropriate (and perhaps required) remedy in every Section 90 case. Although a reliance measure is the logical conclusion of its entire approach, the Restatement itself equivocates by stating that "[a] promise binding under this section is a contract, and full-scale enforcement by normal remedies is often appropriate." 174

The Second Restatement's equivocation may represent a concession to the fact that the reported cases award expectancy relief. Professor Eisenberg nevertheless faults the Restatement for not providing explicitly that "[a] promise that is reasonably relied upon is enforceable to the extent of the reliance."175 Without specifically criticizing the Restatement for not fully embracing reliance damages, other commentators endorse the general principle that reliance damages are appropriate. ${ }^{176}$ Sometimes they qualify their endorsement of

171. See RESTATEMENT (SECOND) OF CONTRACTS $\$ 90 \mathrm{cmt}$ a (1981) ("It is fairly arguable that the enforcement of informal contracts . . . rested historically on justifiable reliance on a promise. Certainly reliance is one of the main bases for enforcement of the half-completed exchange, and the probability of reliance lends support to the enforcement of the executory exchange.").

172. Id. $\$ 90 \mathrm{cmt}$. d.

173. See GLMORE, supra note 9, at 72 ("[T]he unwanted stepchild of Restatement (First) [i.e., reliance] has become 'a basic principle' of Restatement (Second) .....").

174. See RESTATEMENT (SECOND) OF CONTRACTS $\$ 90 \mathrm{cmt}$. d (1981). Commentators recognize the Restatement's equivocation between expectation and reliance as the measure of relief. See MURRAY, supra note 16, $\$ 66$, at 281-83; Metzger \& Phillips, supra note 8, at 500; $c$. Goldstick v. ICM Realty, 788 F.20 456, 464 (7th Cir. 1986) (Posner, J.) ("[T]he Restatement of Contracts implies, if somewhat unclearly, that the value of the promise is the presumptive measure of damages for promissory estoppel ...." (emphasis added)). Some commentators read the Restatement's equivocation as a call for remedial flexibility in $\$ 90$ cases. See, e.g., CAlAMARI \& PERILlo, supra note 8, § 6-6, at 291.

175. See Eisenberg, supra note 8, at 32.

176. See ATIYAH, supra note 9 , at 778 ("[C]ases in which [courts] feel that expectation damages may be too generous, and that reliance damages will serve the ends of justice better, may be treated as promissory estoppel claims ...."); CALAMARI \& PERILLO, supra note 8, § 6-1, at 273 ("[A] promise that is reasonably relied upon is enforceable to the extent of the reliance."); 1 A CORBIN, supra note $13, \S 205$, at 240 (suggesting "remedy ... can be made dependent on the extent of the action or forbearance in reliance"); FARNSWORTH, supra note $4, \S 2.19$, at 100 ("If, however, the ground of the promisee's recovery were regarded as the reliance interest, it would seem appropriate to limit recovery to the value of that interest . . . ."); MURRAY, supra note 16, $\$ 66(\mathrm{~B})(3)$, at 284 ("If the sole reason for enforcing the promise is the detrimental reliance of the promisee and justice requires that reliance [is] to be compensated, it may 
reliance damages to allow for expectation damages or specific performance when the promisor has acted in bad faith ${ }^{177}$ or when reliance damages would be difficult to quantify. ${ }^{178}$ But these commentators agree that reliance is the preferable measure of relief for breach of a Section 90 promise. As the following discussion shows, this position is not supported by the reported cases.

\section{The Cases Cited by the Second Restatement}

The Second Restatement uses five illustrations, each based on the facts of an actual case, to demonstrate the propriety of partial relief-particularly reliance damages-in Section 90 cases. ${ }^{179}$ The reporter's note cites three additional cases to support the same proposition. ${ }^{180}$ Commentators use the same cases to exemplify reliance as the measure of recovery. ${ }^{181}$ As the foundation for a reliance-based theory, these cases merit careful scrutiny.

The first of the Restatement's illustrations ${ }^{182}$ is based on Goodman $v$. Dicker, ${ }^{183}$ in which the defendants, local distributors for Emerson Radio, encouraged the plaintiffs to apply to Emerson for a dealer franchise. The defendants induced the plaintiffs to incur expenses in preparing to establish a franchise by representing that Emerson had accepted the plaintiffs' application and would deliver thirty to forty radios. Emerson neither delivered the radios nor granted the franchise. The plaintiffs sued the defendants for breach of contract. The trial court found that the plaintiffs did not prove the existence of a contract, but held that the defendants were estopped from denying the contract by reason of statements and conduct upon which the plaintiffs relied. The trial court awarded $\$ 1500$ in damages, covering cash outlays by the plaintiffs of $\$ 1150$ and $\$ 350$ in anticipated profits on the sale of thirty radios. ${ }^{184}$ On appeal, the court affirmed but modified the award by denying the lost profits on the ground that the "true measure of damage is the loss sustained by expenditures made in reliance upon the assurance of a dealer franchise." 185

appear that there is precious little reason for awarding expectation damages . . .."); Mark P. Gergen, Liability for Mistake in Contract Formation, 64 S. CAL. L. REv. 1, 37 (1990) ("[I]f the contract theory is promissory estoppel, often only reliance damages are recoverable."); Metzger \& Phillips, supra note 8, at 499 (noting "injustice to the promisor wrought by fully enforcing the promise"); $i d$. at 545 ("Purely gratuitous promises should usually only involve the recovery of reliance losses.").

177. See FARNSWORTH, supra note 4, $\$ 2.19$, at 100-01 (expectation damages appropriate for promisor's bad faith); Metzger \& Phillips, supra note 8, at 500 (recovery of lost profits may depend on promisor's culpability).

178. See CALAMARI \& PERLlo, supra note $8, \S 6-6$, at 291; FARNSWORTH, supra note $4, \S 2.19$, at 101; MURRAY, supra note 16, § 66(B)(3), at 284; Eisenberg, supra note 8, at 26-31; Metzger \& Phillips, supra note 8 , at 544 .

179. See RESTATEMENT (SECOND) OF CONTRACTS $\S 90$ illus. 8-12 (1981).

180. See id. $\$ 90$ reporter's note.

181. See infra notes $186,213,252$ and accompanying text.

182. RESTATEMENT (SECOND) OF CONTRACTS $§ 90$ illus. 8 (1981).

183. 169 F.2d 684 (D.C. Cir. 1948).

184. $J d$.

185. Id. at 685 . 
Commentators often cite Goodman as support for a reliance measure of damages in Section 90 cases. ${ }^{186}$ However, a prerequisite for the application of Section 90 was missing: the defendants did not promise to grant the plaintiffs a franchise, nor did they promise anything else. They simply represented that the plaintiffs' franchise application had been accepted by Emerson. Although the appellate court refers twice to the defendants' conduct in terms of promise, ${ }^{187}$ its summary of the trial court's findings of fact describes the defendants' behavior as "statements," "conduct," and "representations," but never "promise." 188 In limiting the plaintiffs to reliance damages, the appellate court itself describes the defendants' statements as "assurance." 189 While Goodman is sometimes assumed to be a contracts case, the defendants were not in a position to make a promise. They were not employees or agents of Emerson, but merely distributors. Therefore, it is inconceivable that they were promising on Emerson's behalf to grant the plaintiffs a franchise ${ }^{190}$ or that the plaintiffs reasonably interpreted the defendants' statements as a promise. This may explain why the appellate court held for the plaintiffs on the ground of equitable estoppel. ${ }^{191}$ It may also explain why the court did not cite or rely on Section $90,{ }^{192}$ an omission found odd by one advocate of reliance damages. ${ }^{193}$ But because Goodman is a case of misrepresentation, ${ }^{194}$ the appellate court's failure to allude to Section 90 is not at all odd. Its decision to deny expectation damages and to limit the plaintiffs to a tort remedy (reliance damages) is a natural response to a claim based on misrepresentation rather than promise.

The remedy granted in the Restatement's next illustration includes expectation damages. ${ }^{195}$ Appearing under the Restatement comment on partial enforcement, the illustration attempts to establish two propositions: (1) bad faith on the part of the promisor may justify expectation damages; and (2) in the

186. See, e.g., Calamari \& Perillo, supra note 8, \& 6-6, at 290-91; Boyer, supra note 8, at 490; Metzger \& Phillips, supra note 8, at 545 n.489. One commentator notes that seven contracts casebooks include Goodman as support for reliance damages in promissory estoppel cases even though the court never mentioned promissory estoppel. See Slawson, supra note 64, at 202.

187. See Goodman, 169 F.2d at 685 ("[w]e are dealing with a promise"; "the promised dealer franchise").

188. Id. at 684 .

189. Id. at 685 .

190. The Second Restatement defines "promise" as "a manifestation of intention to act or refrain from acting in a specified way." RESTATEMENT (SECOND) OF CONTRACTS § 2(1) (1981). The statements of the defendants in Goodman do not meet this definition because the defendants did not manifest an intention to act in any way but instead represented that a third party (Emerson) would act in a certain way.

191. See Goodman, 169 F.2d at 685.

192. Id.; see also Slawson, supra note 64, at 202.

193. See Boyer, supra note 8 , at 490 .

194. See Barnett \& Becker, supra note 54, at $488 \mathrm{n} .212$ ("II]t is likely that the Goodman court based liability on tortious misrepresentation of fact, rather than on promissory estoppel."); $c f$. Wangerin, supra note 163, at 55 ("Goodman had nothing to do with the idea of flexible damages in contract law reliance situations. Rather, Goodman represented nothing more than a routine application of a somewhat obscure principle in the common law of agency, a principle named the 'Missouri Rule."').

195. See RESTATEMENT (SECOND) OF CONTRACTS $\$ 90$ illus. 9 (1981). 
absence of bad faith, reliance damages are appropriate. ${ }^{196}$ These propositions derive from the Restatement's misreading of Chrysler v. Quimby, ${ }_{197}^{197}$ the case cited as support for the illustration. Quimby was an officer and shareholder in a Chrysler dealership whose principal owner had recently died. Quimby wished to continue the dealership himself. Neely, a regional manager of Chrysler, and Condon, a Chrysler sales executive based in Detroit, both assured Quimby that if certain conditions were met, Chrysler would renew the dealership under Quimby's control. The conditions were met, but Chrysler, upon Neely's advice, refused to renew the dealership. In Quimby's suit for damages under Section 90, the Delaware Supreme Court sustained the lower court's award of two items of damages: (1) Quimby's loss on stock in the dealership that he purchased in reliance on Neely and Condon's assurances; and (2) Quimby's lost profits in the dealership for ninety days, the period during which Chrysler could not have terminated the dealership had it been renewed. ${ }^{198}$

By awarding expectation damages measured by lost profits, Chrysler provides an obvious contrast to Goodman. The Second Restatement attempts to distinguish these cases on the ground that Neely, with Chrysler's approval, deliberately gave Quimby erroneous information to induce him to buy the shares in the dealership owned by the widow of the deceased dealer so that Chrysler could discharge its "moral" obligation to her. The Restatement concludes that Chrysler was liable not only for Quimby's expenses, but also for expectation damages measured by the lost profits because it had acted in bad faith. ${ }^{199}$

The Restatement's distinction is unpersuasive. ${ }^{200}$ The court in Chrysler cited and refused to follow Goodman, but did not distinguish the earlier case on the basis of bad faith. ${ }^{201}$ Without referring to Chrysler's culpability, the court held that Quimby was entitled to the lost profits because they were "a direct result of the breach." ${ }^{202}$ In any event, the defendants in Goodman were hardly innocents. There is no indication in the opinion that they were unaware

196. In setting up the illustration, the Restatement proceeds from the facts of the preceding illustration (derived from Goodman v. Dicker), but adds facts evidencing bad faith on the part of the defendant. See $i d$. at $\S 90$ illus. 9. Based on this factual distinction, the Restatement supports the award of reliance damages in the first illustration and of expectation damages in the second. See MURRAY, supra note $16, \S 66(B)(3)$, at 282 ("On the basis of these two illustrations, it would seem that the remedy is normally limited to the reliance interest but can be expanded to the expectation interest if the promise is made in good [sic] faith.")

197. 144 A.2d 123 (Del. 1958).

198. Id. at 134.

199. See RESTATEMENT (SECOND) OF CONTRACTS $\S 90$ illus. 9 (1981).

200. See Comment, supra note 35, at 588; cf. FARNSwORTH, supra note 4, $\$ 3.26$, at 207 n.22 ("A curious attempt to reconcile ... [Goodman and Chrysler] with respect to the measure of damages appears in Illustrations 8 and 9 to Restatement Second $\S 90 . "$ (emphasis added)).

201. Chrysler, 144 A.2d at 134 (denial of lost profits in Goodman "seems to us to be an unjustifiable restriction as applied to the facts before us. Loss of three months' profits is a direct result of the breach."); see also Knapp, supra note 5, at 56 (Quimby distinguished Goodman not on the basis of culpability, but "on the ground that in Quimby the promised dealership was not to be terminable until at least ninety days had elapsed, and therefore the injury suffered by the plaintiff included a loss of ninety days' profit.").

202. See Chrysler, 144 A.2d at 134. 
of the falsity of their statements, ${ }^{203}$ and they may have been as guilty of bad faith as the defendants in Chrysler. Even if the defendants in Goodman did not know their statements were untrue, they certainly should have investigated before giving the plaintiffs assurances. ${ }^{204}$

Promise explains the difference in the measure of damages in the two cases. The statements at issue in Chrysler were made by Chrysler's employees, not by an independent distributor as in Goodman. Because they were employees, their assurances that Chrysler would renew the dealership could reasonably be interpreted as a promise, and the court construed the statements as a promise. ${ }^{205}$ Although Neely and Condon lacked actual authority to bind Chrysler to renew the dealership, the court concluded that Chrysler was bound by their promise because they had apparent authority. ${ }^{206}$ That the Chrysler court, unlike the Goodman court, relied on Section $90^{207}$ confirms the critical importance of promise in Chrysler. Because the Section 90 promise requirement was met in Chrysler, the court awarded a promissory remedy.

The next illustration ${ }^{208}$ is based on Hoffman v. Red Owl Stores. ${ }^{209}$ Hoffman, who sought a grocery franchise from Red Owl, was assured by a Red Owl agent that Red Owl would grant a franchise if Hoffman invested $\$ 18,000$ in capital in the grocery. Relying on statements by the agent, Hoffman took various steps preparatory to operating a Red Owl franchise, including selling his bakery and purchasing and operating another grocery to gain experience. Negotiations broke down when Red Owl subsequently insisted that Hoffman invest a greater amount of capital, and Hoffman brought suit for damages under Section 90 . On a special verdict, the jury awarded various items of reliance damages. The trial court sustained the verdict except for one item of damages. ${ }^{210}$ Red Owl appealed the entire judgment; Hoffman appealed the decision to set aside the one item of damages. ${ }^{211}$ Adopting Section 90 and applying it to the facts, the Supreme Court of Wisconsin affirmed the trial court on all issues. $^{212}$

Red $O w l$ is one of the most cited and discussed cases arising under Section $90 .{ }^{213}$ The outcome conforms superficially to reliance theory: Hoffman

203. See Goodman v. Dicker, 169 F.2d 684, 684-85 (D.C. Cir. 1948).

204. Cf. Barnett \& Becker, supra note 54, at 489 ("[T]he defendants [in Goodman] had no basis for thinking that the franchisor had made any decision.").

205. See Chrysler, 144 A.2d at 127 ("Quimby's statement that he was promised the franchise is corroborated by the testimony of another applicant for it.").

206. See id. at 130-31.

207. See id. at 133-34.

208. See RESTATEMENT (SECOND) OF CONTRACTS \$ 90 illus. 10 (1981).

209. 133 N.W.2d 267 (Wis. 1965).

210. Id. at $271-72$.

211. Id. at 272 .

212. Id. at 274-77.

213. For a few extended discussions of Red Owl, see CALAMARI \& PERILLO, supra note 8, § 6-5(c), at 289-90; MURRAY, supra note $16, \S 66(\mathrm{~B})(3)$, at 282-83; Jay M. Feinman, Critical Approaches to Contract Law, 30 UCLA L. REV. 829, 854-55 (1983); Henderson, supra note 7, at 358-60; Slawson, supra note 64, 
did not recover the profits he would have earned in a Red Owl franchise. Professor Fried defends limiting Hoffman to reliance damages on the ground that negotiations between the parties had not ripened into "clearly determined promises."214 Fried's reading finds considerable support in the opinion. The summary of facts referred to the statements of Red Owl's agent as "assurances," never as "promises." 215 The trial court repeatedly described the agent's statements as "representations," not as "promises." 216 The supreme court itself conceded that the agreement lacked the terms necessary for a binding contract, but found the agent's statements sufficiently definite to constitute a Section 90 promise. ${ }^{217}$ The court may have found a promise, however, because it saw no other basis on which to hold for Hoffman, ${ }^{218}$ shoehorning the facts into Section 90 in order to afford Hoffman some relief for what the trial judge apparently regarded as (negligent) misrepresentation by Red Owl's agent. $^{219}$

Even if the court really did regard Red Owl's liability as based on promise, Hoffman's failure to recover expectation damages is entirely consistent with a promise-based view of Section 90 . To begin with, Hoffman apparently did not seek expectation damages, nor did he appeal the trial judgment on the ground that he was entitled to expectation damages. ${ }^{220}$ Because the issue was not raised on appeal, the opinion in Red $O w l$ is hardly an endorsement of reliance as the measure of recovery in Section 90 cases. Moreover, expectation damages, if sought, would have been impossible to determine for two reasons. First, the parties had not negotiated terms essential to assessing expectation damages. ${ }^{221}$ Second, profits of a new business like the Red Owl franchise are generally too uncertain to be awarded even in cases of consummated bar-

at 202-04: Comment, supra note 35 , at 584-85.

214. FRIED, supra note 21 , at 24.

215. See Red Owl, 133 N.W.2d at 268-71.

216. See id. at 272 .

217. See id. at $274-75$.

218. See id. at 273 ("[N]o ... theory [other than $\S 90$ ] has been presented to or discovered by this court which would permit plaintiffs to recover."). Under Wisconsin law, Red Owl could not be held liable in an action for fraud or deceit unless its agent had been aware at the time of his statements that they were untrue. There was no evidence of bad faith on the part of the agent. Id. at 273.

219. See Gergen, supra note 176, at 34-46 (Red Owl best explained as case involving negligent misrepresentation).

220. See Red Owl, 133 N.W.2d at 272 (plaintiff only appealed decision to hold new trial on item of reliance damages).

221. See id. at 274 (parties had not negotiated size and cost of grocery store nor terms of lease); Slawson, supra note 64, at 204 ("broken promises [in Hoffman] were too indefinite to provide a basis for awarding expectation damages"). 
gains. ${ }^{222}$ For these reasons, Red $O w l$ may not be read as a rejection of expectancy as the measure of recovery (where feasible) in Section 90 cases. ${ }^{223}$

The next illustration ${ }^{224}$ is based on Miller $v$. Lawlor, ${ }^{225}$ in which the plaintiffs bought residential property in reliance on a neighboring landowner's promise not to develop his own property in a way that would obscure their view. Upon learning of the neighbor's plans to develop his property in violation of his promise, the plaintiffs sought an injunction. The trial court issued an injunction that would terminate whenever the plaintiffs (or their successors) permanently stopped using the view. ${ }^{226}$ On appeal, the Iowa Supreme Court affirmed. ${ }^{227}$

By issuing a negative injunction, the court specifically enforced the promise not to develop the property in certain ways. Miller is thus strong support for a promise-based theory of remedies in Section 90 cases. The Restatement apparently included the illustration under the comment on partial relief because the injunction was to terminate when the plaintiffs (or their successors) ceased to use the view. ${ }^{228}$ But even in cases involving bargains, courts qualify the terms of an equitable decree if necessary to avoid undue hardship on the defendant. ${ }^{229}$ Once the plaintiffs in Miller ceased benefiting from the view, there would be no reason to continue a restriction injurious to the defendant.

222. See, e.g., Gerwin v. Southeastern Cal. Ass'n of Seventh Day Adventists, 92 Cal. Rptr. 111 (Ct. App. 1971) (lost profits of new tavern denied); Cramer v. Grand Rapids Show Case Co., 119 N.E. 227 (N.Y. 1918) (lost profits of new clothing store not proven with sufficient certainty); RESTATEMENT (SECOND) OF CONTRACTS $\S 352 \mathrm{cmt}$. a, illus. 2 (1981) (speculative nature of new business may not permit profits to be determined with reasonable certainty); $c f$. MURRAY, supra note $16, \S 66(\mathrm{~B})(3)$ ), at 283 (outcome in Hoffman understandable because "certainty and foreseeability limit the recovery of damages even where an agreement is complete and the defendant's promise is supported by consideration").

223. Metzger and Phillips have argued that promissory estoppel cases may be divided into " "reasonably discrete subgroups,' each with its own favored measure of damages." Metzger \& Phillips, supra note 8, at 545 (footnote omitted). They cite Red $O w /$ as support for the proposition that "[i]n franchise cases, the tendency is to limit the plaintiff to a reliance-based recovery, with lost profits occasionally allowed." Id. Although this statement implies that courts differ on the appropriate remedy for breach in franchise cases, the reported decisions are easily reconciled. When a definite promise is proved and lost profits can be determined with reasonable certainty, courts award expectation damages measured by the franchise profits that would have been earned but for the promisor's breach. See, e.g., Walters v. Marathon Oil Co., 642 F.2d 1098, 1100-01 (7th Cir. 1981); Chrysler Corp. v. Quimby, 144 A.2d 123, 136 (Del. 1958). When a promise is not proved or lost profits cannot be measured, courts limit the plaintiff's recovery to reliance damages. See, e.g., Goodman v. Dicker, 169 F.2d 684, 685 (D.C. Cir. 1948); Red Owl, 133 N.W.2d 267.

224. See RESTATEMENT (SECOND) OF CONTRACTS $\$ 90 \mathrm{cmt}$. d, illus. 11 (1981).

225. 66 N.W.2d 267 (Iowa 1954).

226. Id. at 271 .

227. Id. at 275 .

228. See RESTATEMENT (SECOND) OF CONTRACTS $\$ 90 \mathrm{cmt}$. d, illus. 11 (1981) ("B's promise is binding, but will be specifically enforced only so long as $A$ and his successors do not permanently terminate the use of the view.").

229. See id. $\$ 358 \mathrm{cmt}$. a (1981) ("[B]y exercising its discretion in fashioning the order, the court may be able substantially to assure the expectations of the parties, without ... unreasonable hardship to the party in breach ...."); $c f$. id. $\S 358(1)$ ("[A]n order of specific performance or an injunction will be ... drawn ... on such terms as justice requires."). See generally YoRIo, supra note 116, \$1.3, at 12 (courts fashion equitable decrees to do justice between parties). 
The injunction was thus limited not to reflect the plaintiffs' reliance, but to avoid undue harm to the defendant.

The final illustration ${ }^{230}$ is based on Kauffman v. Miller. ${ }^{231}$ The plaintiff occupied and made improvements on the defendant's land in the belief that the defendant had promised to bequeath the land to the plaintiff and his wife. After seventeen years, the defendant brought an action in which he succeeded in ejecting the plaintiff from the property. The plaintiff then brought a suit in equity to compel the defendant to account for moneys expended and improvements made by the plaintiff on the property. On appeal, the court granted the plaintiff's request. ${ }^{232}$

The court in Kauffman did not face a choice between expectancy and some lesser remedy because the plaintiff sought an accounting for the improvements, not specific performance or expectation damages. To be sure, if the plaintiff had sought an expectancy measure, the court almost certainly would have denied his claim because he had not established the alleged promise with competent evidence, ${ }^{233}$ as the Restatement itself recognizes. ${ }^{234}$ But in cases involving improvements made in reliance on a proven gratuitous promise, courts routinely grant specific performance. ${ }^{235}$ Kauffman and other improvement cases thus lend no support to reliance theorists. Quite the contrary, these cases establish that when a promise is proven, the plaintiff will obtain a remedy based on the promise, not on reliance.

In support of the illustrations, ${ }^{236}$ the Second Restatement cites three additional cases, none of which undermines expectancy as the measure of relief in Section 90 cases. In Terre Haute Brewing Co. v. Dugan, ${ }^{237}$ the defendant counterclaimed for damages from the plaintiff's refusal to sell beer under an exclusive agency agreement. The court held that anticipated profits could not be recovered because the agreement was indefinite in duration and lacking in mutuality. ${ }^{238}$ Referring to principles of agency law, the court indicated that it might have allowed the defendant to recover expenses incurred during the course of the agency arrangement, but it found the record insufficient to justify recovery on this ground. ${ }^{239}$ The opinion neither cites nor discusses Section 90 ,

230. See RESTATEMENT (SECOND) OF CONTRACTS $\$ 90 \mathrm{cmt}$. d, illus. 12 (1981).

231. 214 Ill. App. 213 (1919).

232. See id. at 218 . The remedy granted-an accounting in equity for the value of the improvements-is restitutionary because it requires the defendant to disgorge a benefit received from the plaintiffs that would be unjust to allow him to retain. See id. at 217 ("II]t would be inequitable and unjust to permit [the defendant] to become enriched ...."). See generally PALMER, supra note 129, \& 1.5 (c).

233. See Kauffman, 214 Ill. App. at 217.

234. See RESTATEMENT (SECOND) OF CONTRACTS $\S 90 \mathrm{cmt}$. d, illus. 12 (1981) ("proof of the terms of the promise ... not sufficiently clear and definite").

235. See sources cited supra note 149.

236. See RESTATEMENT (SECOND) OF CONTRACTS $\$ 90$ reporter's note (1981).

237. 102 F.2d 425 (8th Cir. 1939).

238. Id. at 426-27.

239. Id. at 427-28. 
and the case cannot be read as support for either expectancy or reliance as the measure of recovery in promissory estoppel actions. ${ }^{240}$

In Aiello v. Knoll Golf Club, ${ }^{241}$ the plaintiff sued for a declaration of her interest in land that her father-in-law had allegedly promised to give to her and her husband. The trial court limited the plaintiff's relief to her share of the amount spent by her husband in improving the property. ${ }^{242}$ On appeal, the court affirmed the decision on the ground that " $[t]$ he evidence in support of the alleged promise of gift ... is unconvincing." 243 Not surprisingly, in the absence of a proven promise, the court refused to grant a promissory remedy like specific performance or expectation damages.

In Janke Construction Co. v. Vulcan Materials Co., ${ }^{244}$ the plaintiff sued the defendant for refusing to honor a mistaken bid on subcontracting work. Although the court found no contract, it held the defendant liable under Section 90 because the plaintiff had relied, as the defendant knew it would, on the faulty bid in preparing its own bid on the general contract. ${ }^{245}$ On the measure of recovery, the court stated that "[i]njustice can be avoided only by enforcement of the promise; accordingly, plaintiff is entitled to reliance damages."246

This sentence probably explains why the case is cited under the Restatement comment on partial enforcement: the opinion appears to endorse reliance as the measure of relief in Section 90 cases. But the sentence simultaneously-and somewhat confusingly —endorses "enforcernent of the promise." Moreover, the court actually awarded expectation damages: the difference between the amount the plaintiff ultimately paid to another subcontractor for the work and the amount of the defendant's bid. ${ }^{247}$ Although the court stated that the plaintiff was entitled to "reliance damages," it placed the plaintiff in the position in which it would have been had the defendant honored its bid. ${ }^{248}$

240. Cf. Slawson, supra note 64, at 213 ("[The] Terre Haute court never mentioned promissory estoppel.").

241. 165 A.2d 531 (N.J. Super. Ct. App. Div. 1960).

242. See id. at 533.

243. See id. at 536 .

244. 386 F. Supp. 687 (W.D. Wis. 1974), aff' $d, 527$ F.2d 772 (7th Cir. 1976).

245. See 386 F. Supp. at 691-95.

246. Id. at 695 .

247. See id. at 698; Knapp, supra note 5, at 57 n.35 (court in Janke awarded "the classic expectation remedy").

248. The plaintiff got the work done for the same amount as the defendant's bid: the amount paid to the second subcontractor reduced by an award of damages measured by the difference between the amount paid to the second subcontractor and the amount of the defendant's bid.

Computing reliance damages in subcontract bid cases is complex and sometimes impossible because if the general contractor had computed its bid on the basis of a higher subcontractor's bid, it might not have obtained the job and might have allocated its resources differently. See FARNSWORTH, supra note 4, § 3.25, at 201 n. 18; Becker, supra note 16, at 143-44; Comment, supra note 35, at 568-70. It has been suggested that the routine awarding of expectation damages in such a case may stem from the difficulty of measuring reliance damages rather than from a judicial preference for an expectancy measure. See FARNSWORTH, supra note $4, \S 3.25$, at $201 \mathrm{n} .18$; Comment, supra note 35 , at 583 . However, the judicial opinions generally offer little support for this explanation: courts reflexively enforce the bid by adopting an expectancy measure without considering or rejecting reliance damages on the ground of difficulty of proof. See, e.g., Janke Constr. Co. v. Vulcan Materials Co., 386 F. Supp. 687 (W.D. Wis. 1974), aff'd, 527 F.2d 772 (7th Cir. 
It is interesting to speculate on why the Janke opinion's rhetoric and actual outcome differ. As a federal court hearing a case founded on diversity jurisdiction, ${ }^{249}$ the Wisconsin district court was bound to follow state law under the Erie doctrine. ${ }^{250}$ The court quoted extensively from Hoffman $v$. Red Owl Stores, which appears to support a reliance measure in Section 90 cases. ${ }^{251}$ Although the federal court's dependence on Red Owl may have led it to endorse reliance damages rhetorically, its instinct was still to enforce the bid by awarding expectation damages.

\section{Cases Cited by Other Authorities}

The cases cited by the Second Restatement form the core of support for the proposition that reliance damages are awarded in Section 90 cases. Omitted from the Restatement, but discussed by other commentators, ${ }^{252}$ is Wheeler $v$. White, ${ }^{253}$ the case which comes closest to providing actual support for reliance as the measure of relief. White agreed either to lend or to secure a loan of $\$ 70,000$ to enable Wheeler to raze existing buildings and to construct another building on his property. In return, White was to receive a fee of $\$ 5000$. The loan was to bear interest at "not more than $6 \%$ per annum." Upon White's assurance that a loan would be forthcoming, Wheeler proceeded to raze the existing buildings. When White failed to provide the loan and Wheeler was unable to obtain alternative financing, Wheeler sued, pleading alternatively breach of contract or promissory estoppel and seeking approximately $\$ 60,000$ in reliance damages (the value of the razed buildings and architectural fees) and $\$ 130,200$ in other damages (presumably expected profits on the improvement that was never built due to lack of financing). ${ }^{254}$

A majority of the Supreme Court of Texas sustained the trial court's dismissal of the contract count on the ground that the agreement was indefinite, but reinstated the promissory estoppel count. ${ }^{255}$ As to the measure of relief, the court limited White to reliance damages, stating that lost profits would not be allowed "even if . . provable with certainty."256 The court cited and ap-

1976); Debron Corp. v. National Homes Constr. Corp., 493 F.2d 352, 355, 359 (8th Cir. 1974); Reynolds v. Texarkana Constr. Co., 374 S.W.2d 818 (Ark. 1964); Drennan v. Star Paving Co., 333 P.2d 757 (Cal. 1958).

249. See Janke, 386 F. Supp. at 689.

250. See Erie R.R. v. Tompkins, 304 U.S. 64 (1938).

251. See Janke, 386 F. Supp. at $692-95,697-98$ (citing Hoffman v. Red Owl Stores, 133 N.W.2d 267 (Wis. 1965)). For a discussion of the Red Owl case, see supra text accompanying notes 209-23.

252. See, e.g., CALAMARI \& PERILLO, supra note 8, \$ 6-5(b), at 286-87; FARNSWORTH, supra note 4, § 3.30, at 223-24; MURRAY, supra note 16, § 66(c), at 286-87.

253. 398 S.W.2d 93 (Tex. 1965).

254. See Wheeler v. White, 385 S.W.2d 619, 620 (Tex. Civ. App. 1964).

255. See Wheeler, 398 S.W.2d at $95-97$.

256. Id. at 97. 
parently accepted leading reliance sources, including Fuller and Perdue's article and Goodman v. Dicker. ${ }^{257}$

Although the majority opinion in Wheeler probably constitutes the strongest endorsement by a court of reliance damages, ${ }^{258}$ the majority probably would have reached the same result even if it had been inclined to grant expectation damages in Section 90 cases. If White's promise was too indefinite to support an action for breach of contract, it was also too indefinite to permit awarding expectation damages in an action based on promissory estoppel. ${ }^{259}$ Moreover, even under a contract theory, Wheeler's claim to lost profits would have been denied for failing to satisfy the strictures of the certainty requirement. ${ }^{260}$ This must have been the view of the concurring judge in Wheeler, who joined the judgment of the majority, but on the ground that the agreement at issue was sufficiently definite to constitute a contract. ${ }^{261} \mathrm{He}$ would not have joined the judgment of the majority unless he had decided even on the contract count to limit Wheeler to reliance damages.

Despite the majority's rhetoric in support of reliance, therefore, even Wheeler turns out to be an ambiguous precedent because the same damages would have been allowed under both the contract and promissory estoppel counts. Perhaps the best way of testing whether the case actually supports reliance as the normal measure of relief in Section 90 cases would be to ask what would have happened if Wheeler had been able to secure alternative financing at a higher rate of interest. The concurring judge almost certainly would have allowed Wheeler to recover expectation damages measured by the higher interest costs under the contract count. ${ }^{262}$ With large and unprovable profits not at issue, it seems likely that the majority too would have granted expectation damages under the promissory estoppel count. ${ }^{263}$ If so, Wheeler is a far weaker precedent in support of reliance damages than it initially appears. ${ }^{264}$

257. See id. For discussion of the Fuller and Perdue article and Goodman, see supra text accompanying notes 46-58, 183-94.

258. Cf. MURRAY, supra note 16, at 287 ("Wheeler is one of the relatively few cases to the present time limiting recovery to the reliance interest.").

259. See FARNSWORTH, supra note $4, \S 3.30$, at 224 ("[a]greement [in Wheeler] . . to to indefinite to support recovery based on the expectation interest").

260. See Comment, supra note 35, at 589 ("[Wheeler] would have been hard put to present sufficient evidence of the profitability of the new venture to have satisfied the strictures of the certainty rule.").

261. See Wheeler, 398 S.W.2d at 97-98 (Greenhill, J. concurring).

262. Expectation damages measured by the higher interest costs would be the only item of damages recoverable. With alternative financing, Wheeler would have been able to construct the building as planned. The value of the destroyed buildings would no longer have been recoverable as reliance damages because the new venture would have required their destruction. Wheeler's ability to embark on the new venture would have precluded any claim to profits lost because of lack of financing.

263. Cf. Comment, supra note 35, at 590 ("The most plausible explanation for the choice [of reliance in Wheelerl seems to be the opportunity to limit recovery.").

264. Reliance has not become established in Texas as the measure of relief under $\$ 90$ since Wheeler was decided. The Supreme Court of Texas has not squarely faced the issue of relief under $\S 90$, and in a promissory estoppel case decided seven years after Wheeler, it specifically reserved the question of the appropriate remedy. "Moore" Burger, Inc. v. Phillips Petroleum Co., 492 S.W.2d 934, 939 (Tex. 1972) ("We 
Recent Section 90 cases awarding reliance damages are treated in Professor Farnsworth's treatise on contract law. ${ }^{265}$ Farnsworth cites three cases in which the plaintiff gave up other employment (or an offer of other employment) in reliance on a promise of employment by the defendant. ${ }^{266}$ Although reliance damages measured by the foregone employment were awarded in all three cases, that outcome stems either from the plaintiff's asking only for reliance damages $^{267}$ or from the impossibility of determining expectation damages because the promised employment was terminable at will by the defendant. ${ }^{268}$

Farnsworth also cites two nonemployment cases in which reliance damages were awarded. ${ }^{269}$ In one, the plaintiff apparently did not seek expectation damages, which would have been difficult to prove in any event. ${ }^{270}$ In the other, the court limited the plaintiff to reliance damages because of the "manifestly contingent nature" of the promises at issue. ${ }^{271}$ Considered together, these five cases merely confirm that reliance damages may be awarded when expectation is difficult to prove or when the promise at issue is not sufficiently definite to justify a promissory remedy like specific performance or expectation

need not, and do not decide at this stage of the suit [i.e., promisor's motion for summary judgment] what relief may be granted if [the promisee] establishes the defendant's liability in a conventional trial-whether specific performance, loss of profit damages and exemplary damages, or only reliance damages."). Intermediate appellate courts in Texas sometimes have awarded expectancy relief in promissory estoppel cases decided since Wheeler. See, e.g., Retama Manor Nursing Ctrs. \& Geriatrics v. Cole, 582 S.W.2d 196 (Tex. Civ. App. 1979); Southwest Water Servs. v. Cope, 531 S.W.2d 873 (Tex. Civ. App. 1975); Becker, supra note 16 , at 153 n.112 (citing Texas cases). Texas courts have indicated in some cases that only reliance damages are recoverable under $\S 90$, but that expectation damages would not have been available in those cases for other reasons. See, e.g., Sun Oil Co. v. Madeley, 626 S.W.2d 726, 734 (Tex. 1982) (citing Wheeler); Becker, supra note 16, at 152-53 n.111 (citing Texas cases).

265. See FARNSWORTH, supra note $4, \S 2.19$, at $92-102$. Some of the cases discussed by Farnsworth are cited by other commentators as illustrations of the award of reliance damages under $\$ 90$. See, e.g., CALAMARI \& PERILlo, supra note 8, \$6-6, at 290 n.36 (citing Grouse v. Group Health Plan, Inc., 306 N.W.2d 114 (Minn. 1981)).

266. See FARNSWORTH, supra note $4, \S 2.19$, at 99 n.35.

267. See Hunter v. Hayes, 533 P.2d 952 (Colo. Ct. App. 1975).

268. See Ravelo ex rel. Ravelo v. County of Haw., 658 P.2d 883, 886 (Haw. 1983) ("[Plaintiff] was at best a probationary employee whose employment was terminable without cause at any time."); Grouse v. Group Health Plan, 306 N.W.2d 114, 116 (Minn. 1981) ("employment contract . . . terminable at will"); see also Barnett \& Becker, supra note 54, at 480 (In cases of employment terminable at will, "reliance damages can be calculated with ease, though other remedies could not be.").

The point in the text is made explicit in Grouse: "Since . . . the prospective employment might have been terminated at any time, the measure of damages is not so much what he would have earned from respondent as what he lost in quitting the job he held and in declining at least one other offer of employment elsewhere." 306 N.W.2d at 116.

It may be argued that the plaintiffs in these cases had no damages because the employers could have terminated the contracts at will. But as the court in Grouse explained, "the [plaintiff] had a right to assume he would be given a good faith opportunity to perform his duties to the [defendant's] satisfaction .... once he was on the job." Id. The Grouse plaintiff did not expect to be terminated before beginning work. Thus, he had a legitimate expectancy in the defendant's promise even if expectation damages were speculative because the employment was terminable at will.

269. See FARNSWORTH, supra note $4, \S 2.19$, at 100 n.40, 101 n.43.

270. See Stacy v. Merchants Bank, 482 A.2d 61 (Vt. 1984) (plaintiff sought operating expenses of farm incurred in reliance on defendant's promise of loan).

271. See Green v. Interstate United Mgt. Serv. Corp., 748 F.2d 827, 831 (3d Cir. 1984). 
damages. They offer no support for reliance as the normal measure of relief in Section 90 cases. ${ }^{272}$

It is not particularly noteworthy that courts award reliance damages in Section 90 cases when expectation damages are difficult to prove. Even in cases of bargained-for promises-in which everyone agrees that expectation is the standard measure-courts award reliance damages when expectation damages cannot be established with reasonable certainty. ${ }^{273}$ In the cases discussed above, the circumstances were such that the courts would have awarded reliance damages even if the promises had been supported by consideration.

What is noteworthy is that all of the leading cases cited by reliance theorists to support reliance are commercial in nature. ${ }^{274}$ If courts were truly concerned with protecting reliance in these cases, they would have awarded expectation damages to compensate for opportunities presumably foregone in reliance on the promises. ${ }^{275}$ The courts instead adopted an out-of-pocket measure of damages that fails to compensate for lost opportunities. The reliance theorists' pure case for reliance damages is the donative promise, where reliance is unlikely to take the form of foregone opportunities. ${ }^{276}$ Yet the remedy for breach of a proven donative promise is always expectation.

We have discussed the cases awarding reliance damages at length because reliance theorists and the Second Restatement suggest that they show reliance to be a standard remedy under Section 90. Even these cases do not support the reliance theorists' claim. Courts award reliance damages only when no promise has been made or proven or when expectation damages cannot be computed. Perhaps some of these cases are subject to more than one fair interpretation, but cases awarding reliance damages for any reason are anomalous. Cases awarding expectation or specific performance overwhelm the few cases awarding reliance damages in number and consistency. 277

272. Courts sometimes limit the plaintiff to reliance damages when the plaintiff is the low bidder for a government contract, but the government entity mistakenly awards the contract to another bidder. See, e.g., Baxter's Asphalt \& Concrete, Inc. v. Liberty County, 406 So. 2d 461 (Fla. Dist. Ct. App. 1981); State Mechanical Contractors v. Village of Pleasant Hill, 477 N.E.2d 509 (Ill. App. Ct. 1985). These cases in no way represent a preference for reliance damages because the courts expressly base their holdings on an unwillingness to make taxpayers pay two contractors for the same job. Although these cases arise under $\S 90$, the wrong on the part of the government entity is not a breach of promise so much as a violation of its bid procedures, for which reliance damages, measured by the harm caused, may be the appropriate measure of recovery. In any case, the courts presume that in a case between private parties expectation damages would be awarded.

273. See Restatement (SeCond) of Contracts $\$ \$ 349,352$ (1981); Calamari \& Perillo, supra note $8, \S 14-9$, at 603-04; FARNSWORTH, supra note $4, \S 12.16$.

274. See supra text accompanying notes 183-94, 206-23, 253-64.

275. See supra text accompanying notes 50-51.

276. See supra text accompanying note 56.

277. See Slawson, supra note 64, at 202 ("Of the possibly hundreds of reported decisions applying promissory estoppel since 1932, only three have been widely read as holding that damages . . . are limited to the reliance measure."). 


\section{Summary}

The notion that the appropriate measure of relief for breach of a Section 90 promise is reliance damages permeates academic commentary, convincing even the leading exponent of promise theory that courts generally award reliance damages in Section 90 cases. ${ }^{278}$ The reported cases tell a very different tale. The routine remedy for breach of a Section 90 promise is specific performance or expectation damages. Reliance damages are awarded in rare cases, but only if no promise is made or proven or if expectation damages are difficult to determine. Otherwise, courts grant expectancy relief.

The impulse to enforce Section 90 promises by expectancy relief is so strong that courts have resisted an academic consensus in support of reliance damages. ${ }^{279}$ Reliance theorists offer no persuasive explanation for the fact that judges routinely grant expectancy relief. It is telling that courts grant expectation damages even when the value of the promise greatly exceeds the promisee's reliance, ${ }^{280}$ an outcome inconsistent with the conventional, reliancebased view of Section 90 . It is also revealing that the only substantive explanation for judicial decisions awarding reliance damages is a defect in the promise or in the defendant's proof of the promise. That expectancy relief (if measurable) yields to reliance damages in cases of defective promise but prevails in cases of relatively insignificant reliance confirms that in the courts, Section 90 is about enforcing promises, not protecting reliance.

\section{INDUCEMENT AND DETRIMENT ARE NEITHER NECESSARY NOR SUFFICIENT UNDER SECTION 90}

If reliance were the basis of Section 90 , courts presumably would condition recovery on reliance and detriment, and allow recovery whenever reliance is proven. In fact, courts do neither. They sometimes allow recovery when the promise has neither induced the promisee to change her behavior, nor caused her to suffer detriment. Conversely, they sometimes deny recovery when the promisee has relied to her detriment.

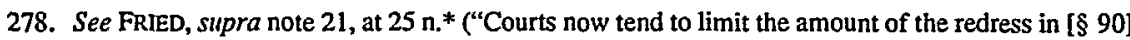
cases to the detriment suffered through reliance."); $c f$. DOUGLAS LAYCOCK, MODERN AMERICAN REMEDIES 25 (1985) ("Recovery usually is limited to reliance losses" in promissory estoppel cases).

279. Even commentators who support expectancy relief under $\$ 90$ in the context of commercial promises do not endorse expectancy in cases of donative promises, which were the cases that led to the inclusion of $\S 90$ in the First Restatement. See Farber \& Matheson, supra note 16, at 937-38; Slawson, supra note 64, at 211; Comment, supra note 35, at 563. Another commentator appears to endorse expectation damages, but predicts that reliance will become the usual measure of relief in $\S 90$ cases. See Henderson, supra note 7 , at $378-79$.

280. See, e.g., In re Estate of Bucci, 488 P.2d 216 (Colo. Ct. App. 1971) (expectation damages of $\$ 17,000$ awarded where reliance loss was $\$ 2000$ ); Ricketts v. Scothorn, 77 N.W. 365 (Neb. 1898) (\$2000 judgment enforced where reliance loss was approximately \$520); Young v. Overbaugh, 39 N.E. 712 (N.Y. 1895) (specific performance granted even though promisee did not suffer reliance loss because rental value of house she occupied exceeded amount husband had expended on improvements). 


\section{A. Courts Do Not Require Inducement or Detriment}

According to the First Restatement, a promise is enforceable under Section 90 only if it induces action (or forbearance) by the promisee. ${ }^{281}$ The Second Restatement also requires that the promise induce action (or forbearance), ${ }^{282}$ but dispenses with proof of inducement in cases of charitable subscriptions and marriage settlements. ${ }^{283}$ Leading commentators also state that the promise must induce action (or forbearance) by the promisee. ${ }^{284}$ Conditioning enforcement on actual inducement is consistent with the view that the objective of Section 90 is to protect promisees who have suffered loss in reliance on a promise. If the promisee would have acted (or forborne) even in the absence of the promise, the promise did not cause any loss. A reliancebased theory of Section 90 also requires that the induced action (or forbearance) have resulted in detriment to the promisee. ${ }^{285}$ If the promisee actually benefitted or would have sustained an identical loss even without acting in reliance on the promise, then enforcement of the promise cannot be based on protecting the promisee from loss suffered in reliance.

A promissory view of Section 90 , by contrast, requires neither actual inducement nor detriment to enforce a promise. So long as the possibility of definite and substantial action (or forbearance) by the promisee was conveyed to the promisor, the promise is likely to have been sufficiently well considered to justify enforcement. Although actual inducement and detriment may strengthen the case for legal intervention, a court proceeding from a promissory perspective might enforce the promise in the absence of both. ${ }^{286}$

Despite the contrary position of leading commentators and both Restatements, courts do not require actual inducement under Section $90 .{ }^{287}$ Nor do they insist that the promisee suffer a detriment by relying on the promise. ${ }^{288}$ The most obvious examples of promises enforceable in the absence of inducement are charitable subscriptions and marriage settlements, for which the Second Restatement created a separate subsection of Section $90{ }^{289}$ The new

281. See RESTATEMENT OF CONTRACTS $\S 90$ (1932).

282. See RestaTEMENT (SECOND) OF CONTRACTS $\$ 90(1)$ (1981).

283. See id. $\S 90(2)$ ("A charitable subscription or a marriage settlement is binding ... without proof that the promise induced action or forbearance.").

284. See, e.g., CALAMARI \& PERILLO, supra note $8, \S 6-1$, at 272; 1A CORBIN, supra note 13, § 200, at 218; FARNSWORTH, supra note 4, $\$ 2.19$, at 97-98; MURRAY, supra note $16, \S 66(\mathrm{~B})$, at 279; Boyer, supra note 8, at 471; Fuller \& Perdue, supra note 8, at 69.

285. See Calamari \& Perillo, supra note 8, § 6-1, at 273 ("It would seem that injury is what is required because without injury there would be no injustice in not enforcing the promise.").

286. Substantial action (or forbearance) by the promisee serves as evidence that a promise was in fact made. In the absence of action (or forbearance), a court might insist that the promise be established by other convincing evidence. See infra text accompanying notes 331-32.

287. See Farber \& Matheson, supra note 16, at 910 (identifiable detriment is not required for enforceability of $\S 90$ promise).

288. See infra text accompanying notes 306-07.

289. See RESTATEMENT (SECOND) OF CONTRACTS § 90(2) (1981). 
subsection, however, may not go far enough in reflecting the reported cases. By dispensing merely with proof of inducement, the Restatement implies that inducement is still required, but need not be proven. Comment (f) elaborates on the meaning of the new subsection by stating that a probability of reliance suffices in the context of charitable subscriptions and marriage settlements. ${ }^{290}$ Even as clarified, however, the Restatement's position is more restrictive than the cases, in which charitable subscriptions are enforced despite convincing evidence that the charity did not change position in reliance on the pledge, ${ }^{291}$ and marriage settlements are enforced without even an allegation of reliance. ${ }^{292}$

Charitable subscriptions and marriage settlements pose a significant threat to the view that the objective of Section 90 is to protect a promisee who has suffered loss in reliance on the promise. The most common explanation links the enforceability of these promises to social policies favoring the activities of organized charities and the institution of marriage. ${ }^{293}$ This rationale has an obvious ad hoc quality. For example, it fails to explain why the legal system would not enforce a promise to pay for a daughter's college expenses or for a son's medical operation in the absence of actual inducement given our strong

290. See RESTATEMENT (SECOND) OF CONTRACTS $§ 90 \mathrm{cmt}$. $\mathrm{f}$ (1981).

291. E.g., Salsbury v. Northwestern Bell Tel., 221 N.W.2d 609 (lowa 1974); Jewish Fed'n v. Barondess, 560 A.2d 1353 (N.J. Super. Ct. Law. Div. 1989); see also P.H.C.C.C., Inc. v. B.J. Johnston, 340 N.W.2d 774, 776 (Iowa 1983) (reliance not necessary under standard announced in Salsbury); CALAMARI \& PERILLO, supra note 8 , § 6-2(d), at 280 ("In the majority of the cases the charity would not be able to show substantial injurious reliance."); MURRAY, supra note $16, \S 66(A)(4)$, at $277-78$ (recent cases indicate charity did not rely on promise); Shattuck, supra note 8, at 933-34 (charity often unable to point to action taken in reliance).

Some commentators have suggested that although a charity may not rely on a particular pledge to a general fund campaign, it may rely on the aggregate of subscriptions to the campaign. See Knapp, supra note 5, at 61; Shattuck, supra note 8, at 934; cf. 1 A CORBIN, supra note 13, $\$ 205$, at 241 ("Action in reliance will usually be found to be much greater than the amount of any single subscription."). Courts may be willing to enforce all charitable pledges in order to protect a charity from harm suffered in aggregate reliance. See Knapp, supra note 5, at 61. Professor Becker has convincingly rebutted this argument, however. See Becker, supra note 16, at 136-37. Because charities are repeat players in the legal system, they are aware of the rules governing enforcement of charitable pledges. If such pledges are unenforceable, a charity will simply discount the total pledges by a factor reflecting the percentage of pledges normally repudiated. The charity then would rely only on the discounted amount and would not be hurt by the refusal of the legal system to enforce charitable subscriptions. See Maryland Nat'1 Bank v. United Jewish Appeal Fed'n, Inc., 407 A.2d 1130, 1138 (Md. 1979) (charity "made due allowance for the fact that a certain percentage of the pledges would not be paid").

292. See De Cicco v. Schweizer, 117 N.E. 807 (N.Y. 1917); Phalen v. United States Trust Co., 78 N.E. 943 (N.Y. 1906); Shadwell v. Shadwell, 3 L.T.R. 628 (C.B. 1860) (Eng.). In two of these cases, there were strong dissents arguing that the promise should not be enforced either because the plaintiff suffered no detriment by marrying or because the plaintiff had not alleged that he would not have married in the absence of the promise. See Phalen, 78 N.E. at 951 (O'Brien, J., dissenting) (no detriment suffered); Shadwell, 3 L.T.R. at 630-31 (Byles, J., dissenting) (no allegation that plaintiff would not have married in absence of promise).

293. See CALAMARI \& PERILLo, supra note 8, § 6-2(d), at 280-81; FARNSworTH, supra note 4, \$ 2.19, at 98; cf. RESTATEMENT (SECOND) OF CONTRACTS $\$ 90, \mathrm{cmt}$. $\mathrm{f}$ (1981) ("Courts have traditionally favored charitable subscriptions and marriage settlements."). 
social commitment to children, education, and health care. ${ }^{294}$ Moreover, if the policy favoring charities is so powerful, why do some courts refuse to enforce charitable pledges that are not directed to specific and substantial charitable projects? ? $^{295}$

The social policy rationale for special treatment of charitable pledges and marriage settlements also fails to explain why other promises are enforced under Section 90 without proof of actual inducement. ${ }^{296}$ When the issue was raised at the 1965 proceedings of the American Law Institute, a member of the audience stated that in the context of "charitable subscriptions, marriage settlements, and other gifts ... it's perfectly apparent that you don't have to have inducement in any formal sense." ${ }^{297} \mathrm{He}$ proposed, therefore, changing Section 90 to reflect the absence of a requirement of "real inducement" in the cases. ${ }^{298}$ As revised, Section 90 diverged from his proposal by dispensing only with proof of inducement (and not with inducement itself) and by omitting "other gifts" from this special treatment. For the Restatement to have embraced the proposal in its entirety would have been inconsistent with its view that the objective of Section 90 is to protect promisees who have suffered loss in reliance on a promise.

Although the dilemma faced by the Restatement is easy to appreciate, the solution chosen actually conforms less to the reported cases than does the proposal. ${ }^{299}$ To begin with, courts dispense with a requirement of inducement (not just with proof of inducement) in the context of charitable subscriptions and marriage settlements. Moreover, courts enforce other promises under Section 90 without proof of inducement and even in the face of strong evidence that the promise did not induce an actual change in the promisee's position. ${ }^{300}$ In fact, only rarely do courts seem to require proof that the promisee would have acted differently had the promise not been made. ${ }^{301}$

294. As we will later explain, promises are enforced under $\S 90$ in the absence of actual inducement if the promisor should reasonably have expected that the promise might induce definite and substantial action (or forbearance) by the promisee. See infra text accompanying notes 310-12, 344.

295. See, e.g., Jordan v. Mount Sinai Hosp., 276 So. $2 d 102$ (Fla. Dist. Ct. App. 1973), aff' d, 290 So. 2d 484 (Fla. 1974); Maryland Nat'I Bank v. United Jewish Appeal Fed'n, Inc., 407 A.2d 1130 (Md. 1979). For a promise-based explanation of why courts divide over the enforceability of charitable pledges, see infra text accompanying notes 351-54.

296. See infra text accompanying notes 310-12.

297. 1965 Proceedings, stipra note 91 , at 297 (remarks of Mr. Boskey) (emphasis added).

298. See id.

299. See Farber \& Matheson, supra note 16, at 910 (role of reliance in determining liability has diminished as there is no longer requirement of identifiable detriment in $\S 90$ cases).

300. See infra text accompanying notes 310-12.

301. In Feinberg v. Pfeiffer Co., 322 S.W.2d 163 (Mo. Ct. App. 1959), the plaintiff sought to enforce a promise of a pension on the ground that the promise had induced her to retire. The defendant argued that the plaintiff had not established that she would not have retired in the absence of the promise. Upon reviewing the testimony in the trial court, the court disagreed. See id. at 166 . The court's response to the defendant's argument may be read as an acceptance of the view that $\$ 90$ requires actual inducement. However, the court's finding of actual inducement made it unnecessary to address the issue of whether or not the promise could be enforced in the absence of actual inducement. 
Consider, for example, Devecmon v. Shaw, ${ }^{302}$ the classic case in which a nephew alleged that his uncle had promised that he would pay the expenses of a trip to Europe. The nephew took the trip and sought reimbursement from the uncle's estate for the expenses incurred. When the estate refused, the nephew sued for breach of contract. The court held that if the uncle made a promise, it was enforceable because it was supported by the consideration of incurring expenses on the trip. ${ }^{303}$

Although the court upheld the promise on the basis of consideration, commentators regard taking the trip and incurring expenses as conditions to a gift and not really bargained-for consideration. ${ }^{304}$ The Devecmon opinion poses serious difficulties for the view that the objective of Section 90 is to protect a promisee who has suffered loss in reliance on a promise. The court did not require the nephew to prove that he would not have gone to Europe and incurred the expenses in the absence of the promise. On the contrary, the court indicated that it would have enforced the promise even if the nephew would have taken the trip without the promise. ${ }^{305}$ The court also found irrelevant the possibility that the nephew had benefitted from the expenditures. ${ }^{306}$

Other decisions demonstrate even more clearly that the promisee need not suffer a detriment for a promise to be enforceable under Section $90 .{ }^{307}$ Moreover, cases of gratuitous promises to pay insurance premiums show that actual

When courts adduce absence of reliance as a ground for denying relief, the decision usually can be explained on some other ground, such as absence of a promise, unforeseeability of action in reliance, or failure to satisfy a condition of the promise. See infra text accompanying notes 324-30.

302. 14 A. 464 (Md. 1888).

303. See id. at 465 .

304. See, e.g., CALAMARI \& PERILLO, supra note $8, \S 6-2$, at 275; 1 A CORBIN, supra note $13, \S 203$, at 231. The Second Restatement apparently concurs because it cites the case in support of an illustration under $\S 90$. See RESTATEMENT (SECOND) OF CONTRACTS $\S 90$ reporter's note (1981).

305. Devecmon, 14 A. at 464-65 ("It might very well be, and probably was the case, that the plaintiff would not have taken a trip to Europe at his own expense. But, whether this be so or not, the testimony would have tended to show that the plaintiff incurred expense at the instance and request of the deceased ...." (emphasis added)); cf. 1A CORBIN, supra note 13, § 203, at 231-32 (nephew took trip "in reliance on the promise and might not have taken it otherwise" (emphasis added)).

306. Devecmon, $14 \mathrm{~A}$. at 465 ("It is nothing to the purpose that the plaintiff was benefitted by the expenditure of his own money."); see also Hamer v. Sidway, 27 N.E. 256 (N.Y. 1891) (promise to pay $\$ 5000$ enforced without regard to whether promisee benefitted from satisfying conditions of promise).

307. In Huhtala v. Travelers Ins. Co., 257 N.W.2d 640 (Mich. 1977), the defendant promised to make a fair settlement of a pending lawsuit against its insured for injuries sustained by the plaintiff. As a consequence, the plaintiff failed to bring the suit within the applicable statute of limitations. The court held that the plaintiff had a claim to a fair settlement based on the subsequent promise, which might be enforced under $\S 90$. See id. at 647 . The court also held that the plaintiff was not required to show that the defendant's insured would have been liable in the original suit. Id. at 646 . Thus, the plaintiff was not required to show that she suffered a detriment in failing to prosecute the original suit in reliance on the defendant's promise of a fair settlement.

In Katz v. Danny Dare, Inc., 610 S.W.2d 121 (Mo. Ct. App. 1980), the court enforced a promise of a pension because the plaintiff had relied on the promise by retiring. But if the plaintiff would have been fired anyway, as the trial court found, the plaintiff suffered no detriment by retiring. See id. at 124 . Yet the court held that it was irrelevant that the plaintiff might have been fired had he not retired. Id. 
inducement is not necessary for enforcing such promises ${ }^{308}$ In a common scenario, the insured receives a notice from the insurance company (or from a party with an interest in insured property) that a premium is due on an outstanding insurance policy. When the insured reveals that she is unable to pay the premium, the defendant promises to pay it for her. When the defendant fails to pay the premium and the event insured against occurs, the insured succeeds under Section 90 in holding the defendant liable for the amount that would have been payable under the policy had the premium been paid. ${ }^{309}$ In such a situation, it is very likely that the promise did not induce the promisee to change position. ${ }^{310}$ If, as the promisee stated, she was unable to pay the premium, the policy would have lapsed even if the defendant had not made the promise. Despite the likely absence of actual inducement, courts hold the promisor liable for breaching the promise to pay the premium. ${ }^{311}$ The Restatement itself seems to recognize that actual inducement is not required because it lists factors in lieu of reliance which may make an insurance promise enforceable. ${ }^{312}$

One commentator has suggested that requiring proof of actual inducement in Section 90 cases might place too great a burden on the promisee. ${ }^{313}$ If she has acted in the manner contemplated by the promise, it may be difficult for her to prove that she would have acted differently in the absence of the promise. According to this view, courts dispense with proof of actual inducement not because inducement is unnecessary to the promisee's cause of action, but because it may be too hard to prove. ${ }^{314}$ This argument, however, fails to explain the reported cases. Courts enforce promises under Section 90 even when the evidence shows that the promise did not induce a change of behavior by the promisee, and they sometimes indicate that the outcome does not depend on actual inducement. ${ }^{315}$ By contrast, courts in other contexts condition recovery on proof of inducement. ${ }^{316}$

308. See, e.g., Spiegel v. Metropolitan Life Ins. Co., 160 N.E.2d 40 (N.Y. 1959); East Providence Credit Union v. Geremia, 239 A.2d 725 (R.I. 1968).

309. See Spiegel, 160 N.E.2d 40; East Providence Credit Union, 239 A.2d 725.

310. Other commentators have noted the absence of actual reliance in the insurance cases. See, e.g., Barnett \& Becker, supra note 54, at 466-67; Feinman, supra note 7, at 695.

311. Because the insurance cases pose a serious threat to a reliance-based theory of $\S 90$, it is not surprising that commentators have been creative in trying to explain the outcomes. See, e.g., FARNSWORTH, supra note 4, \$ 2.19, at $98 \mathrm{n} .31$ (insured in East Providence Credit Union may have relied on credit union's promise by driving rather than garaging car).

312. See RESTATEMENT (SECOND) OF CONTRACTS $\$ 90 \mathrm{cmt}$. e (1981) (formality, part performance, commercial setting, or potential benefit to promisor may make gratuitous insurance promise enforceable); cf. infra text accompanying notes $356-57$ (discussing factors listed by Restatement).

313. See Feinman, supra note 7, at 695 ("Some courts, recognizing the difficulty of proving specific reliance on a promise to insure, conclude that the failure to procure the promised coverage is sufficient to raise an inference of reliance.").

314. See id.

315. See supra text accompanying notes 299-311.

316. See, e.g., Wisconsin Knife Works v. National Metal Crafters, 781 F.2d 1280, 1288 (7th Cir. 1986) (defendant required to prove inducement for waiver to be effective). 
Typically, courts deal with recurring problems of proof not by dispensing with evidentiary inquiry altogether, but by manipulating the burden of proof. ${ }^{317}$ Courts could do the same in Section 90 cases by setting up a rebuttable presumption of reliance or by requiring the promisor to disprove reliance. Thus, once the promisee proves that she acted in the manner contemplated by the promise, courts might either permit the inference that she did so in reliance on the promise or require the promisor to prove that the promise did not induce the promisee to act. ${ }^{318}$ In fact, courts do neither, but instead treat proof of the promisee's action as conclusive on the question of inducement, suggesting that inducement is not a requirement of Section $90 .{ }^{319}$

While the difficulty of proving reliance does not explain the cases, difficulty of disproving reliance permits the Restatement and other commentators to continue to assert that actual inducement is required under Section 90 . When the promisee has acted in the way contemplated by the promise, it is usually hard to disprove that she did so in reliance on the promise, because it is difficult to show that she would have acted the same way even in the absence of the promise. Marriage settlements and charitable subscriptions had to be excepted from the Restatement's normal requirement of inducement because absence of inducement is virtually certain in such promises. ${ }^{320}$ If the Restatement has not entirely eliminated the requirement of inducement entirely, ${ }^{321}$ it may be because in many cases it is difficult to show that the promise was not the cause of action taken by the promisee.

Even granting that some courts do not require actual inducement under Section 90 , skeptics may argue that other courts deny relief on the ground that the promisee did not act (or forbear) in reliance on the promise. ${ }^{322}$ Moreover,

317. See Fleming JaMes, JR. \& Geoffrey C. HAZARD, JR., CIVIL PROCEDURE § 3.9, at 146 (3d ed. 1985) ("Considerations of fairness, convenience, and policy sometimes relieve a plaintiff from proving, in the first instance, a fact which clearly belongs to his or her claim . ...”; id. §§ 7.8, 7.9; MICHAEL M. MARTIN, BASIC PROBLEMS OF EVIDENCE \$ 3.01-.04, at 41-49, (6th ed. 1988); Edward W. Cleary, Presuming and Pleading: An Essay on Juristic Immaturity, 12 STAN. L. REv. 5 (1959); $c f$. Basic, Inc. v. Levinson, 485 U.S. 224 (1988) (rebuttable presumption of reliance under SEC's Rule 10b-5); Affiliated Ute Citizens v. United States, 406 U.S. 128 (1972) (same); Shores v. Sklar, 642 F.2d 462, 468 (5th Cir. 1981) (same), cert. denied 459 U.S. 1102 (1983). See generally UNIF. R. EVID. 301(a) (1974) (effect of presumption).

318. Cf. De Cicco v. Schweizer, 117 N.E. 807, 810 (N.Y. 1917) ("The springs of conduct are subtle and varied. One who meddles with them must not insist upon too nice a measure of proof that the spring which he released was effective to the exclusion of all others.").

319. See JAMES \& HAZARD, supra note $317, \S 7.9$, at 326 ("When the law conclusively presumes the presence of $B$ from $A$, this means that the substantive law no longer requires the existence of $B$ in cases where $A$ is present, although it hesitates as yet to say so forthrightly.").

320. Two people in love who want to marry are unlikely to let their plans turn on a promise of a marriage setuement. A charity conducting a large general fund campaign is unlikely to alter its behavior in response to a relatively small pledge.

321. The Second Restatement has moved toward eliminating an inducement requirement in the context of promises to procure insurance, see RESTATEMENT (SECOND) OF CONTRACTS $\S 90 \mathrm{cmt}$. e (1981), probably because these promises are, next to marriage settlements and charitable subscriptions, the easiest about which to prove the absence of actual inducement. See supra text accompanying notes $308-11$, and infra text accompanying notes 354-57.

322. See cases cited infra notes $326-30$. 
when enforcing a Section 90 promise, courts often state that the promisee acted (or forbore) in reliance on the promise. ${ }^{323}$ Both phenomena are easily reconciled with the view that courts do not require actual inducement.

Although courts sometimes give absence of reliance as a reason for refusing to enforce a promise under Section 90 , some other factor, such as lack of a promise, unforeseeability of reliance, or failure to comply with a condition of the promise, can usually explain the outcome. An analysis of the ten cases denying relief that the Second Restatement cites under Section 90 illustrates this point. ${ }^{324}$ Six of the cases rest on grounds other than absence of reliance. ${ }^{325}$ In one of the four cases citing absence of reliance as a reason for denying relief, the promisee failed to satisfy a condition of the promise. ${ }^{326}$ In another case, the court interpreted the alleged promise to be merely an expression of intention to consider performing at a future date rather than a firm commitment. ${ }^{327}$ In the third case, the court found no promise. ${ }^{328}$ In the fourth case, the court refused to enforce a charitable pledge not directed to a specific project. Not only did the charity not take action, but specific action by the charity was not reasonably foreseeable by the promisor. ${ }^{329}$ In sum, none of the cases cited by the Restatement supports the position that actual inducement is a prerequisite for obtaining relief. The pattern also holds for cases not cited by the Restatement. Although absence of reliance may be cited for denying the plaintiff relief, usually some other factor mandates the same outcome. ${ }^{330}$

323. See, e.g., Miller v. Lawlor, 66 N.W.2d 267 (Iowa 1954) (reliance by buying property); LuskHarbison-Jones, Inc. v. Universal Credit Co., 145 So. 623 (Miss. 1933) (reliance by forbearing to insure); Feinberg v. Pfeiffer Co., 322 S.W.2d 163 (Mo. Ct. App. 1959) (reliance by retiring); Ricketts v. Scothorn, 77 N.W. 365 (Neb. 1898) (reliance by quitting job).

324. See RESTATEMENT (SECOND) OF CONTRACTS $\$ 90$ reporter's note (1981).

325. See Intermar, Inc. v. Atlantic Richfield Co., 364 F. Supp. 82 (E.D. Pa. 1973) (no reasonable probability that plaintiff would succeed in proving promise); Northern Commercial Co. v. United Airmotive, 101 F. Supp. 169 (D. Alaska 1951) (promise interpreted as requiring only that insurance be kept effective for reasonable time); Tiffany, Inc. v. W.M.K. Transit Mix, Inc., 493 P.2d 1220 (Ariz. Ct. App. 1972) (promissory estoppel does not defeat statute of frauds defense unless promise was that writing would be executed or that statute had already been satisfied); Tauber v. Jacobson, 293 A.2d 861 (D.C. 1972) (absence of promise and statute of frauds defense); Rayden Eng'g Corp. v. Church, 151 N.E.2d 57 (Mass. 1958) (allegation of promise to insure varied from actual promise to use best efforts to insure); R.J. Taggart, Inc. v. Douglas County, 572 P.2d 1050 (Or. Ct. App. 1977) (bid did not state that it was irrevocable).

326. See Corbit v. J.I. Case Co., 424 P.2d 290, 301 (Wash. 1967).

327. See In re Johnson's Estate, 346 N.Y.S.2d 283, 288 (Sur. Ct. 1973).

328. See Division of Labor Law Enforcement v. Transpacific Transp. Co., 137 Cal. Rptr. 855, 860-61 (Ct. App. 1977).

329. See Jordan v. Mount Sinai Hosp., Inc., 276 So. 2d 102, 108 (Fla. Dist. Ct. App. 1973), aff d, 290 So. $2 \mathrm{~d} 484$ (Fla. 1974).

330. See, e.g., Dovenmuehle, Inc. v. K-Way Assocs., 388 F.2d 940, 947 (7th Cir. 1968) (trial court could credit denial of promise); Pitts v. McGraw-Edison Co., 329 F.2d 412, 416 (6th Cir. 1964) (Tennessee state courts had not yet adopted $\$ 90$ ); Blatt v. University of S. Cal., 85 Cal. Rptr. 601, 607 (Cal. App. 1970) (no allegation of promise); Maryland Nat'l Bank v. United Jewish Appeal Fed'n of Greater Wash., Inc., 407 A.2d 1130, 1138 (Md. 1979) (no specific goal prompted charitable pledge and therefore no awareness of future reliance); Ervin v. Ervin, 458 A.2d 342, 344-45 (R.I. 1983) (no evidence of promise); Hayes v. Plantations Steel Co., 438 A.2d 1091, 1094-96 (R.I. 1982) (defendant did not expect retirement to result from statement, which may not have been promise anyway). 
The many cases that adduce reliance as a reason for enforcing the promise are consistent with a promise-based explanation of Section 90 , for reliance plays important roles even under a promissory theory of the section. The prospect that a promise might induce definite and substantial action by the promisee was critical to Williston's original, promissory conception of Section 90. Moreover, foreseeability of reliance remains essential in Section 90 cases (except some cases involving charitable pledges). ${ }^{331}$ The occurrence of substantial action makes it more likely that the promisor should have expected the prer $s=0$ induce that action. Substantial action by the promisee also serves an evidentiary function by increasing the likelihood that a promise was in fact made. A court proceeding from a promissory perspective may be reluctant to credit the plaintiff's allegations in the absence of substantial action or other convincing evidence of a promise. ${ }^{332}$

Other factors may contribute to the promisee's frequent references to reliance. Action taken by the promisee is essential to her claim if, as is often the case, that action is a condition to obtaining the benefit of the promise..$^{333}$ The insistence of both Restatements that the promise induce action may have become a self-fulfilling prophecy to the extent that courts, even if they do not require actual inducement, emphasize reliance when it occurs. Then, too, a court writing an opinion in favor of the promisee has every reason to "gild the lily" by emphasizing the harm suffered by the promisee in relying on the promise. Finally, it is possible to speak of a person acting in "reliance" on a promise without meaning that the promise actually induced the action taken. Thus, when courts say that the promisee "relied" on the promise, they may mean only that she acted in contemplation of the promise, not that she would have acted differently had the promise not been made. ${ }^{334}$ Without actual inducement,

331. See infra text accompanying notes 336-38.

332. See Wisconsin Knife Works v. National Metal Crafters, 781 F.2d 1280, 1287 (7th Cir. 1986) (Posner, J.) ("Reliance ... is a common substitute for consideration in making a promise legally enforceable, in part because it adds something in the way of credibility to the mere say-so of one party . . . [T] danger of successful fabrication is less if the promisor has actually incurred a cost, has relied."); Michael B. Metzger, The Parol Evidence Rule: Promissory Estoppel's Next Conquest?, 36 VAND. L. REV. 1383, 1432 (1983) ("The reliance that the promissory estoppel doctrine requires . . . can serve [an] evidentiary function."); $c f$. Knapp, supra note 5, at 61 (absent reliance, courts might insist on other credible evidence of charitable pledge).

333. See, e.g., Devecmon v. Shaw, 14 A. 464 (Md. 1888) (condition of promise that nephew travel to Europe); I.G. Katz v. Danny Dare, Inc., 610 S.W.2d 121 (Mo. Ct. App. 1980) (condition of promise that employee retire); Feinberg v. Pfeiffer Co., 322 S.W.2d 163 (Mo. Ct. App. 1959) (same); De Cicco v. Schweizer, 117 N.E. 807 (N.Y. 1917) (condition of promise that couple marry); Hamer v. Sidway, 27 N.E. 256, 257 (N.Y. 1891) (condition of promise that plaintiff abstain from "drinking liquor[,] using tobacco, swearing, and playing cards or billiards for money").

334. Professor Corbin sometimes uses the word "reliance" in the sense described in the text. Although he sometimes states that "reliance" is essential, see 1 A CORBIN, supra note $13, \S 200$, at 218 , he indicates at other points in his treatise that by "reliance" he means only that the promisee must act in contemplation of the promise. For example, in his analysis of Devecmon v. Shaw, 14 A. 464 (Md. 1888), he states that the nephew took the trip "in reliance on the promise and might not have taken it otherwise." Id. $\$ 203$, at 231-32 (emphasis added). In his catalogue of questions bearing on the appropriate remedy for breach of a $\S 90$ promise, he asks: "Was the action of the promisee actually induced . . . by the promise?" Id. $\$ 205$, at 246. If actual inducement was essential in Corbin's view of $\$ 90$, then its absence would defeat the 
however, the promise is not the cause of any loss suffered by the promisee, and reliance theory cannot explain why the promise is enforced.

\section{B. Courts Sometimes Deny Recovery Despite Reliance}

Courts sometimes deny recovery under Section 90 even though the promisee has relied to her detriment on a promise. ${ }^{335}$ This outcome is usually justified on the ground that reliance was not foreseeable by the promisor at the time of the promise. ${ }^{336}$ If reliance were the basis of Section 90 , harm suffered by the promisee would mandate a remedy and foreseeability by the promisor would not matter. ${ }^{337}$ In contrast, the courts' insistence on foreseeability is entirely consistent with a theory of Section 90 based on serious promise. ${ }^{338}$ The promisee's behavior is not central in a promissory theory. The prospect of reliance is enough to make a promise binding, even if reliance does not in fact follow, and action in reliance is not enough if the reliance was not foreseeable.

\section{Summary}

In their influential article, Fuller and Perdue offer two possible explanations for the prevalence of expectancy relief in Section 90 cases: "[E]ither the expectation interest is preferred as a measure of recovery because of its greater

promisee's claim, and inducement would not be listed merely as a factor to be considered in determining the remedy for breach.

335. See IA CORBIN, supra note 13, $\$ 209$, at 268 (promise may not be enforced despite action in reliance where promisor "had no sufficient reason to foresee that [the action] would take place in reliance on his promise"); FARNSwORTH, supra note 4, $\$ 2.19$, at 99 ("Even if the promisee relied on the promise, the promisor is not liable if the promisor had no reason to expect any reliance at all or had reason to expect reliance but not of the sort that occurred.'); 1 SAMUEL WILLISTON, A TREATISE ON THE LAW OF CONTRACTS $\S 112$, at 448 (3d ed. 1957) ("II]n some cases . . . even though the promisee has incurred detriment, the promise has been held unenforceable."); Comment, supra note 35, at 577 (requirement of foreseeability "has been imposed with sufficient stringency for it to be said that actual foresight is virtually required").

336. See, e.g., Atkinson v. American Agency Life Ins. Co., 299 S.E.2d 600, 602 (Ga. Ct. App. 1983) (promise not of character that defendant should have foreseen action in reliance and thus not enforceable under promissory estoppel); Berryman v. Kmoch, 559 P.2d 790, 794 (Kan. 1977) (option promise not enforceable because acts in reliance could not reasonably be expected); Hill v. Corbett, 204 P.2d 845, 847-48 (Wash. 1949) (promise not enforceable if promisor did not foresee action in reliance at time of promise).

337. See Eisenberg, supra note 8, at 21-22.

338. See supra text accompanying notes $87-88,91-100$.

Professor Farnsworth seems to read one case, Sanders v. Arkansas-Missouri Power Co., 593 S.W.2d 56 (Ark. Ct. App. 1980), as not requiring foreseeability by the promisor of the action taken by the promisee in reliance on the promise. See FARNSwORTH, supra note $4, \S 2.19$, at 99 n.33. In Sanders, an employer promised full pay and benefits to an employee for as long as the employee remained disabled due to an injury on the job. Relying on the promise, the employee built a home that he fitted with special wheelchair accommodations. The court held that the promise would be binding if the trial court determined on remand that the employee's reliance was reasonable. See 593 S.W.2d at 58-59; FARNSWORTH supra note 4, $\$ 2.19$, at 112-14. Although the court does not seem to have required that the employer foresee the particular action taken by the employee in reliance on the promise, nothing in the opinion suggests that the employer did not know of the employee's plans. In any event, Professor Farnsworth seems to recognize that Sanders is at most an exception to the requirement that the promisor have reason to foresee the particular act in reliance that occurs. See id. at 99. 
definiteness ... or the factor of reliance serves to release the impulse to compel men to make good their promises ...." ${ }^{339}$ Although they argue that there is no way of demonstrating which is the "true" explanation, they concede that if the "definiteness" explanation prevailed, we might expect the award of reliance damages whenever the reliance interest offered a relatively certain standard for computing damages. ${ }^{340}$ If, however, reliance is merely the catalytic agent that stimulates the impulse to hold people to their promises, then ease of measuring the reliance interest is irrelevant, and expectation damages will be awarded in any event. ${ }^{341}$

We now know that, even when they are readily calculable, reliance damages are not awarded in Section 90 cases. We also know that expectancy is the routine measure of relief. Fuller and Perdue's alternate explanation for the prevalence of expectancy relief comes fairly close to the thesis of this Article. Reliance plays a role under Section 90, but it is at most the role of directing courts to a more fundamental objective: enforcing certain types of promises. Various circumstances can make a promise enforceable, including a bargain or meeting the requirements set out by courts under Section 90 . In the collection of factors that make a promise enforceable, there is nothing special about reliance. Some nonbargain promises are enforced in the absence of actual inducement or detriment. Some nonbargain promises are not enforced despite detrimental reliance by the promisee. And even when reliance contributes to making a promise binding, it triggers a judicial impulse to enforce the promise with expectation damages or specific performance, rather than merely to compensate for reliance.

\section{THE IMPORTANCE OF PROMISE}

The routine award of expectancy relief, the absence of a requirement of inducement or detriment, and the refusal in some cases to grant relief despite detrimental reliance all show that the reported cases cannot be explained on the basis of reliance. In fact, reliance theory does not explain why in Section 90 cases courts insist that there be a promise. ${ }^{342}$ If the basis of recovery were

339. Fuller \& Perdue, supra note 8 , at 69.

340. See id. at 69-70.

341. See id. at 70 .

342. The central importance of a promise is illustrated well by a series of Iowa Supreme Court cases that arose from a campaign to raise money to found a college. In the first, Pappas v. Hauser, 197 N.W.2d 607,609 (Iowa 1972), the defendant signed a pledge card stating: "I/we intend to subscribe to the College Founder's Fund the sum of $\$ 3,000$." Due to lack of funds, the college closed after a year, and a receiver was appointed. Upon the defendant's failure to pay the pledge, the receiver sued for breach of contract. The parties stipulated to testimony of a conversation during which a representative of the college stated that the pledge was not intended to be binding. After finding that this testimony was admissible on the issue of interpreting the meaning of the pledge, the court held the pledge unenforceable because it was not a promise but merely an expression of an intention to pay and was not meant to be legally binding. See id. at 612-13.

The facts of Pappas v. Bever, 219 N.W.2d 720 (Iowa 1974), decided two years later, were identical in all material respects except that there was no evidence of a conversation between the defendant and the 
harm caused by the defendant's conduct, it should not matter whether the conduct constituted a promise. ${ }^{343}$

The critical and difficult question about Section 90 in the courts is not whether to protect reliance, but whether to enforce the promise at issue. It is neither sufficient nor necessary that the promise induce the promisee to rely to her detriment. Every promise may influence the promisee's behavior, and yet not every relied-upon promise is enforceable. What distinguishes enforceable from unenforceable promises is the quality of the commitment made by the promisor.

Separating serious from frivolous promises is one of the functions of the doctrine of consideration. This function was served in Section 90 of the First Restatement by the requirement that the promisor reasonably expect the promise to induce definite and substantial action (or forbearance). Although the Second Restatement dropped this requirement, in every case it cites under subsection 1 of Section 90 that grants relief, the promise was expected to induce particular and substantial action (or forbearance). ${ }^{344}$

college on the effect of the pledge. The court again held the pledge unenforceable because the pledge card expressed an intention to pay and was not a promise. Id. at 721-22. In the third case decided later the same year, Salsbury v. Northwestern Bell Tel. Co., 221 N.W.2d 609 (Iowa 1974), the defendant did not sign the standard pledge card. Instead, its agent mailed a letter to the college stating that "the contribution from Northwestern Bell Telephone Co. has been approved" and the "\$15,000 contribution will be made over a three year period, in three equal payments." Citing a public policy of favoring charitable institutions, the court held that the defendant was bound to the subscription despite the absence of either consideration or reliance. Id. at 610, 612-13.

The public policy rationale offered by the court in Salsbury is wholly unpersuasive as a way to distinguish among these cases. If a policy of favoring charities had been determinative, the court would have held for the plaintiff in Bever as well as in Salsbury. (Although the extrinsic evidence may have prevented the court in Hauser from upholding the pledge, the court in Bever might very easily have interpreted the pledge as binding if a policy of favoring charities had been determinative. For further discussion of the public policy rationale, see supra text accompanying notes 293-96.) Not only was the plaintiff in each case a charity, but it was the very same charity.

The real distinction between Salsbury and the prior cases is the quality of the defendant's commitment. Rather than expressing a mere intention to pay, the defendant's letter in Salsbury constituted a promise to make a contribution. See Salsbury, 221 N.W.2d at 610 ("The trial court held the letter was a promissory undertaking."). The court itself recognized the critical importance of promise in distinguishing among the cases when it stated at the conclusion of its opinion (after citing Bever) that "where a subscription is unequivocal the pledgor should be made to keep his word." 221 N.W.2d at 613 .

343. See infra text accompanying notes 360-61.

344. See D'Oench, Duhme \& Co. v. FDIC, 315 U.S. 447 (1942) (creditors expected to loan money based on promissory note executed by defendant); Goodman v. Dicker, 169 F.2d 684 (D.C. Cir. 1948) (incurring expenses preparatory to obtaining franchise); Janke Constr. Co. v. Vulcan Materials Co., $386 \mathrm{~F}$. Supp. 687 (W.D. Wis. 1974) (use of bid in computing bid on general contract), aff'd, 527 F.2d 772 (7th Cir. 1976); Crail v. Blakely, 505 P.2d 1027 (Cal. 1973) (failure to revise will); Burgess v. California Mut. Bldg. \& Loan Ass'n, 290 P. 1029 (Cal. 1930) (loan by third party); Graddon v. Knight, 292 P.2d 632 (Cal. App. 1956) (failure to insure); Chrysler Corp. v. Quimby, 144 A.2d 123 (Del. 1958) (purchase of stock in franchise); Kauffman v. Miller, 214 Ill. App. 213 (1919) (making improvements on land); Miller v. Lawlor, 66 N.W.2d 267 (Iowa 1954) (purchase of land); Greiner v. Greiner, 293 P. 759 (Kan. 1930) (making improvements on land); Devecmon v. Shaw, 14 A. 464 (Md. 1888) (taking European trip); McLearn v. Hill, 177 N.E. 617 (Mass. 1931) (discontinuance of legal action); Huhtala v. Travelers Ins. Co., 257 N.W.2d 640 (Mich. 1977) (not bringing legal action); Lusk-Harbison-Jones, Inc. v. Universal Credit Co., 145 So. 623 (Miss. 1933) (failure to insure); Feinberg v. Pfeiffer Co., 322 S.W.2d 163 (Mo. Ct. App. 1959) (retirement); Ricketts v. Scothorn, 77 N.W. 365 (Neb. 1898) (quitting job); Aiello v. Knoll Golf Club, 165 A.2d 531 (N.J. Super. Ct. App. Div. 1960) (building home on land); Horsfield v. Gedicks, 118 A. 275 (N.J. Ch. 1922) 
The promisor's contemplation of particular and substantial reliance is important not in and of itself, but because it signals the quality of her commitment. Other circumstances may establish that a promise was sufficiently well considered for legal intervention. Thus, a promisor who expects a benefit in return for her promise is fairly charged with the seriousness of the promise. The promisee's situation may also indicate that the promisor's commitment was well considered. In cases of marriage settlements, for example, promises may be enforced even in the absence of actual inducement because of the possibility, foreseen by the promisor, that the promisee might change her behavior in reliance on the promise. ${ }^{345}$ Alternatively, promises made in the marriage context may be regarded as inherently serious because they involve what is traditionally viewed as a very important part of personhood. ${ }^{346}$

The central importance of promise under Section 90 is well illustrated by charitable pledges and by promises to procure insurance. Pledges are often enforced when there is no reliance. ${ }^{347}$ Indeed, even the normal Section 90 foreseeability requirement may not be satisfied by a pledge to a general fund campaign of a charity because the promisor does not contemplate any particular

(making improvements on land), aff'd mem., 124 A. 925 (N.J. 1924); Spiegel v. Metropolitan Life Ins. 160 N.E.2d 40 (N.Y. 1959) (failure to insure); Siegel v. Spear \& Co., 138 N.E. 414 (N.Y. 1923) (failure to insure); Hamer v. Sidway, 27 N.E. 256 (N.Y. 1891) (foregoing pleasures); Spector v. National Cellulose Corp., 48 N.Y.S.2d 234 (Sup. Ct. 1943) (creditors' loaning money), aff' d, 47 N.Y.S.2d 311 (1944); East Providence Credit Union v. Geremia, 239 A.2d 725 (R.I. 1968) (failure to insure); Hoffman v. Red Owl Stores, 133 N.W.2d 267 (Wis. 1965) (sale of bakery).

Four of the cases cited by the Second Restatement are covered by subsection 2 of $\S 90$. See Salsbury v. Northwestern Bell Tel. Co., 221 N.W.2d 609 (Iowa 1974) (charitable subscription); De Cicco v. Schweizer, 117 N.E. 807 (N.Y. 1917) (marriage settlement); Phalen v. United States Trust Co., 78 N.E. 943 (N.Y. 1906) (marriage settlement); In re Field's Estate, 172 N.Y.S.2d 740 (Sur. Ct. 1958) (charitable subscription). One case was decided under principles of agency law rather than under $\$ 90$. See Terre Haute Brewing Co. v. Dugan, 102 F.2d 425 (8th Cir. 1939); see also supra text accompanying notes 237-40 (discussing Terre Haute decision).

345. See De Cicco v. Schweizer, 117 N.E. 807, 809 (N.Y. 1917) (Cardozo, J.) ("It is enough that the natural consequence of the defendant's promise was to induce them to put the thought of rescission or delay aside." (emphasis added)).

346. Cf. id. at 810 (Cardozo, J.) (the law "strains ... to hold men to the honorable fulfillment of engagements designed to influence in their deepest relations the lives of others").

347. See supra text accompanying note 291 .

In an influential article, Dean Boyer catalogued a variety of rationales based on the consideration doctrine that courts have used for more than a century to enforce charitable pledges. See Boyer, supra note 129 , at 646 . He concluded that the facts in many of these cases do not support the courts' findings that the pledges were supported by bargained-for consideration. Id. at 649-52. Other commentators have reached the same conclusion. See, e.g., IA CORBIN, supra note 13, $\$ 198$, at 209; 1 WILLISTON, supra note 335, $\S 116$, at 474; Shattuck, supra note 8 , at 932-33. Boyer argued that the cases could be explained on the basis of detrimental reliance by the charity. Boyer, supra note 129 , at 652-53. Consistent with this rationale, he also advocated in another article that the measure of recovery should be reliance damages. See Boyer, supra note 8, at 487. But Boyer's reliance theory cannot fully explain the reported cases: charitable subscriptions may be enforced even without the charity's reliance. See Shattuck, supra note 8, at 933. Moreover, the remedy granted is measured by the amount of the pledge rather than by the extent (if any) of the charity's reliance. See, e.g., Salsbury v. Northwestern Bell Tel. Co., 221 N.W.2d 609 (Iowa 1974); In re Field's Estate, 172 N.Y.S.2d 740 (Sur. Ct. 1958): 1A CORBIN, supra note 13, $\$ 205$, at $241-42$ (courts have always awarded full recovery of pledge in charity cases); Shattuck, supra note 8, at 933 ("measure of recovery [is] now universally a judgment for the full amount of the subscription"). 
act by the charity in reliance on the pledge. ${ }^{348}$ Yet many courts enforce this type of charitable subscription. ${ }^{349}$ Other courts pointedly reject the Restatement's invitation to enforce pledges outside of the normal requirements of Section $90 .^{350}$ These courts emphasize the lack of consideration and the fact that the pledge was not directed to a specific project expected to be undertaken by the charity. ${ }^{351}$

Although courts differ somewhat on the enforcement of pledges, the likelihood of enforcement generally varies with the quality of the promisor's commitment. Perhaps the easiest case is a pledge made in exchange for consideration furnished by the charity, such as naming a building for the donor. ${ }^{352}$ Somewhat more problematic - but still routinely enforced ${ }^{353}$ - are pledges made not in return for consideration, but with the promisor's knowledge that the charity might use the pledged funds for some particular and substantial project. If the promisor does not receive consideration or contemplate reliance by the charity, the risk is greater that the pledge was not seriously considered. Not surprisingly, therefore, some courts refuse to enforce such a pledge. Other courts apparently regard every promise made to a charitable institution engaged in good work as a promise that ought to be enforced. While it may seem wrong to break any promise, it may seem more wrong for someone to break a promise to support the work of an organization that she has recognized (by her promise) selflessly does good work.

Like charitable pledges, promises to procure insurance may be enforced in the absence of reliance by the promisee. ${ }^{354}$ Here, too, enforcement depends on the quality of the promisor's commitment. The Second Restatement states that courts should be cautious about enforcing insurance promises because of the severe consequences to the promisor: for failing to pay a small premium, she may be liable for the amount of a very large policy. ${ }^{355}$ Despite its warning, the Restatement proceeds to catalogue various factors that may justify

348. See Jewish Fed’n v. Barondess, 560 A.2d 1353, 1354 (N.J. Super. Ct. Law Div. 1989) ("[I]n reality, a charity does not rely on a particular subscription when planning its undertakings.").

349. See, e.g., Salsbury v. Northwestern Bell Tel. Co., 221 N.W.2d 609 (Iowa 1974); In re Field's Estate, 172 N.Y.S.2d 740 (Sur. Ct. 1958); see also RESTATEMENT (SECOND) OF CONTRACTS $§ 90$ illus. 17 (1981) (supporting enforcement of charitable promise to university based on highly attenuated theory of reliance).

350. See, e.g., Jordan v. Mount Sinai Hosp., 276 So. $2 d 102$ (Fla. Dist. Ct. App. 1973), aff' $d$, 290 So. 2d 484 (Fla. 1974); Maryland Nat'l Bank v. United Jewish Appeal Fed'n Inc., 407 A.2d 1130 (Md. 1979).

351. See, e.g., Jordan, 276 So. 2d at 108; Maryland Nat'l Bank, 407 A.2d at 1138.

352. See Woodmere Academy v. Steinberg, 363 N.E.2d 1169 (N.Y. 1977).

353. Even jurisdictions that refuse to enforce naked contributions are willing to validate pledges directed towards a specific charitable project. Thus, the Maryland Supreme Court, even while refusing to enforce a charitable pledge to a general fund campaign, discussed with approval earlier cases that enforced charitable pledges targeted for particular activities. Maryland Nat'l Bank, 407 A.2d at 1134-35; see also Jordan, 276 So. $2 \mathrm{~d}$ at 105 (in refusing to enforce naked pledge, court discussed with apparent approval cases in other jurisdictions enforcing subscriptions directed towards specific projects).

354. See supra text accompanying notes 308-12.

355. RESTATEMENT (SECOND) OF CONTRACTS $\$ 90 \mathrm{cmt}$. e (1981); see also 1A CORBIN, supra note $13, \S 209$, at 267 ("[I]f the promise is held binding, the promisor becomes himself an insurer and his liability may be very heavy."). 
enforcement even absent actual reliance, including the formality of the promise, part performance by the promisor, a commercial setting, or potential benefit to the promisor. ${ }^{356}$

If the objective of Section 90 were to protect reliance, the formality of a promise could not substitute for reliance. On the contrary, formality matters only as evidence of the promisor's seriousness. Similarly, partial performance indicates that the promise was made with the intention of performing. Promises made in a commercial setting or with the expectation of obtaining a potential benefit are more likely to be serious than promises made in a purely donative context. ${ }^{357}$ Thus, each of the factors adduced by the Restatement indicates that the promise was likely to have been well considered; none relates to reliance by the promisee.

In addition, the promisor's commitment is generally likely to be serious because of the possibility, even if remote, that the promise might keep the promisee from obtaining insurance. This possibility should alert the promisor to the potentially severe consequences of making and breaching her promise. Thus, the Restatement's argument for caution in enforcing these promises actually cuts the other way: a promise to procure insurance is almost certainly serious because performance involves relatively little cost and the consequence of not performing may be substantial loss to the insured.

Cases that fall within subsection 1 of Section 90, cases of charitable pledges and cases of insurance promises, all involve nonbargain promises. Enforcement depends not on the promisee's reliance, but on the seriousness of the promisor's commitment. The central importance of commitment is also shown by the many cases in which a fault with the promise leads the court to deny the plaintiff any relief. ${ }^{358}$ In nine of the ten cases cited by the Second Restatement in which the plaintiff does not obtain any relief, the outcome turns largely on a problem with the promise. ${ }^{359}$ When the plaintiff obtains partial relief,

356. See RESTATEMENT (SECOND) OF CONTRACTS $\$ 90 \mathrm{cmt}$. e (1981).

357. See Farber \& Matheson, supra note 16, at 920-24; Charles L. Knapp, Book Review, 82 MiCH. L. REV. 932, 947-48 (1984) (reviewing E. ALLAN FARNSwORTH, CONTRACTS (1982)).

358. See, e.g., Dovenmuehle v. K-Way Assocs., 388 F.2d 940 (7th Cir. 1968) (trial court could credit denial of promise); Blatt v. University of S. Cal., 85 Cal. Rptr. 601 (Ct. App. 1970) (no allegation of promise); Ervin v. Ervin, 458 A.2d 342 (R.I. 1983) (insufficient evidence of promise).

359. See Intermar v. Atlantic Richfield Co., 364 F. Supp. 82 (E.D. Pa. 1973) (no reasonable probability that plaintiff would prove promise); Northern Commercial Co. v. United Airmotive, 101 F. Supp. 169 (D. Alaska 1951) (promise interpreted as requiring only that insurance be kept in effect for reasonable time); Tiffany v. W.M.K. Transit Mix, Inc., 493 P.2d 1220 (Ariz. Ct. App. 1972) (promissory estoppel does not defeat statute-of-frauds defense unless promise was that writing would be executed or that the statute had already been satisfied); Division of Labor Law Enforcement v. Transpacific Transp. Co., 137 Cal. Rptr. 855 (Ct. App. 1977) (no promise): Tauber v. Johnson, 293 A.2d 861 (D.C. 1972) (absence of promise); Rayden Eng'g Corp. v. Church, 151 N.E.2d 57 (Mass. 1958) (allegation of promise to insure varied from actual promise to use best efforts to insure): In re Johnson's Estate, 346 N.Y.S. 283 (Sur. Ct. 1973) (statement interpreted as expression of intention rather than promise); R.J. Taggart v. Douglas County, 572 P.2d 1050 (Or. Ct. App. 1977) (bid did not state that it was irrevocable); Corbit v. J.I. Case Co., 424 P.2d 290 (Wash. 1967) (failure to satisfy condition of promise).

In the tenth case cited by the Restatement in which relief was denied, the court refused to enforce a charitable pledge that was clearly a promise. See Jordan v. Mount Sinai Hosp. 276 So. 2d 102 (Fla. Dist. 
virtually the only substantive explanation is a defect in the promise or in the defendant's proof of the promise.

When courts award reliance damages in cases of defective promise or misrepresentation, ${ }^{360}$ they are vindicating the plaintiff's interest in not being harmed by the defendant's conduct. The wrong resembles that done by driving an automobile negligently and injuring a pedestrian. By putting the plaintiff in the same position as before the deficient statements were made, reliance damages serve the same objective served by damages awarded to compensate for injury caused by negligence. ${ }^{361}$

The theory of liability in these cases differs radically from that in the typical Section 90 case. $^{362}$ Courts enforce promises under Section 90 when they view the promises as serious and deserving of enforcement qua promise; they do not enforce them out of solicitude for promisees. The promisor's commitment may be shown to be sufficiently serious by her contemplation of particular and substantial reliance, by the formality of the promise, by the situation of the promisee, or by a chance of benefit to the promisor. The importance to courts of promise explains why the remedy for breach of a Section 90 promise is invariably expectancy relief (if measurable); why the absence of inducement and detriment is irrelevant; why some promises are not enforced despite detrimental reliance; and why the outcome (in terms of both liability and remedy) generally turns on some aspect of promise. ${ }^{363}$

\section{CONCLUSION}

The central question of contract law is: Which promises ought to be enforced? Fuller and Perdue assumed that the legal rules used to sift out promises for enforcement were based on interests of promisees, and many other scholars

Ct. App. 1973), aff $d, 290$ So. $2 d 484$ (Fla. 1974). But because the pledge was neither supported by consideration, nor directed to a specific project, the pledge may not have been seriously considered by the promisor.

360. See supra text accompanying notes 186-94, 215-19.

361. See DAN B. DOBBS, HANDBOOK ON THE LAW OF REMEDIES 540 (1973) ("[D]amages awarded in personal injury actions are aimed at compensating the victim or making good his losses.").

362. According to the thesis of this Article, cases of defective promise or misrepresentation are not strictly $\S 90$ cases because they do not always contain a promise that meets the requirements of the section. See, e.g., D'Ulisse-Cupo v. Board of Directors, 520 A.2d 217 (Conn. 1987) (no liability under $\S 90$ because no promise made, but possible liability for negligent misrepresentation). Some of these cases may be decided under $\$ 90$ because courts may recognize the merit of the plaintiff's claim, but lack other vehicles through which to afford the plaintiff relief. For example, in Hoffman v. Red Ow1 Stores, 133 N.W.2d 267 (Wis. 1965), § 90 was the only basis to hold for the plaintiff because Wisconsin courts refused to treat negligent misrepresentation as an actionable tort. See id. at 273; see also supra text accompanying notes 218-19.

363. The conclusions in the text merely describe the reported cases. We have not attempted to explain why promise is so fundamental to the judicial conception of $\S 90$. Perhaps courts are expressing moral indignation at breaking seriously made promises. See Morris Cohen, The Basis of Contract, 46 HARV. L. REV. 553, 571-72 (1933); Knapp, supra note 357, at 951. Or perhaps courts are affirming a personal autonomy notion that people should be free to bind themselves by promise and others should be able to take them at their word. See FRIED, supra note 21, at 14-17. See generally DOUGLAS LAYCOCK, THE DEATH OF THE IRREPARABLE INIURY RULE 255-64 (1991) (revieving moral arguments for keeping promises). 
agree. ${ }^{364}$ Promisees have legitimate interests in promises being kept, and studying those interests can be very enlightening. In the context of Section 90 promises, however, those interests neither determine which promises are enforced nor the extent to which they are enforced. Judges respond instead to "the impulse to hold men to their promises." 365

Conventional wisdom maintains that Section 90 holds promisors liable because a person who makes a promise causing another to act in reliance should compensate the other for her injury. However, when courts routinely grant specific performance or expectation damages, they do more than simply protect promisees from harm. Similarly, when courts grant relief despite convincing evidence that the promise neither induced reliance nor caused detriment, and when they deny relief despite detrimental reliance, their motivation cannot be to protect promisees from injury caused by reliance on a promise.

Like the rest of contract law, Section 90 is about promises. What distinguishes enforceable promises from unenforceable ones under Section 90 are the proof and quality of the promisor's commitment. Whenever the criteria for a serious commitment by the promisor are satisfied, the promisee obtains full expectancy relief (if feasible) for the breach. Issues of both liability and remedy under Section 90 turn on promise, not reliance.

Section 90 has greatly expanded the scope of civil liability in twentiethcentury American law. Contrary to received wisdom, that expansion has occurred in the contractual context of promise rather than the tort-related context of reliance. Far from evidencing the death of contract, the application of Section 90 by the courts demonstrates that promise is more vital than ever. 
